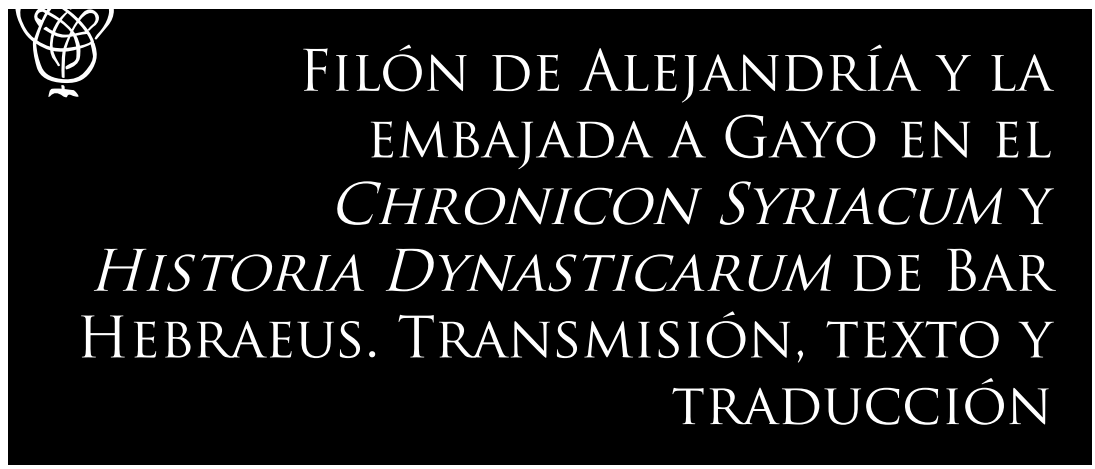

\section{Paola Druille}

Daniel Asade
[CONICET - Universidad Nacional de la Pampa]

[paodruille@gmail.com]

[Museo de Farmacobotánica "Juan A. Domínguez"

Facultad de Farmacia y Bioquímica, UBA]

[daniel.asade@outlook.com]
Resumen: Nuestro trabajo ofrece una traducción del siríaco y árabe al castellano de las noticias en torno a la embajada a Gayo y Filón de Alejandría contenidas en Chronicon Syriacum y Historia Dynasticarum. Para esto, hemos dividido nuestro estudio en dos partes. En la primera presentaremos las evidencias para la embajada a Gayo y Filón. Comenzaremos con un rastreo de las referencias vinculadas con este evento en las fuentes griegas, latinas y siríacas, en especial Contra Flaco y Embajada a Gayo de Filón, Antigüedades judías de Josefo, Historia eclesiástica de Eusebio, Chronicon de Jerónimo y Chronicon de Miguel el Sirio. Los datos transmitidos por cada una de estas fuentes serán puestos en comparación con las noticias anotadas en las crónicas de Bar Hebraeus. En la segunda parte realizaremos una síntesis de la estructura de estas crónicas siríaca y árabe, y su correspondiente traducción y notas.

Palabras clave: Chronicon syriacum - Historia Dynasticarum - Bar Hebraeus - Filón de Alejandría - embajada a Gayo
Philo of Alexandria and the embassy to Gaius in the Chronicon Syriacum and Historia Dynasticarum of Bar Hebraeus. Transmission, Text and Translation

Abstract: Our work offers a translation from Syriac and Arabic into Spanish of the news about the embassy to Gayo and Philo of Alexandria contained in Chronicon Syriacum and History Dynasticarum. For this, we have divided our study into two parts. In the first we will present the evidences for the embassy to Gaius and Philo. We will begin with a trace of the references related to this event in Greek, Latin and Syriac sources, especially Flaccus and Embassy to Gaius of Philo, Jewish Antiquities of Josephus, Ecclesiastical History of Eusebius, Chronicon of Jerome and Chronicon of Michael the Syrian. The data transmitted by each of these sources will be compared with the news recorded in the chronicles of Bar Hebraeus. In the second part we will make a synthesis of the structure of these Syriac and Arabic chronicles, and their corresponding translation and notes.

Keywords: Chronicon Syriacum - Historia Dynasticarum - Bar Hebraeus - Philo of Alexandria - Embassy to Gaius 


\section{Introducción}

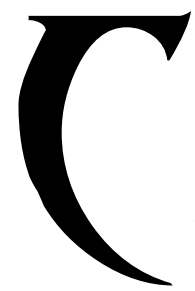

hronicon Syriacum o civil (Chronographia $=$ "L. Chronicorum") ${ }^{1}$ es una de las obras más estudiadas de Bar Hebraeus. Contiene una historia secular del mundo conocido hasta el siglo XIII, dividida en once series o dinastías: 1) los patriarcas de Adán a Moisés, 2) los jueces, 3) los reyes de los hebreos, 4) los reyes de los caldeos, 5) los reyes de los medos, 6) los reyes de los persas, 7) los reyes de los griegos paganos, 8) los reyes de los romanos desde Augusto hasta Justino II, 9) los reyes de los cristianos griegos bizantinos, desde Tiberio hasta Heraclio, 10) los reyes árabes hasta el año 1258, y 11) los reyes de los hunos ${ }^{2}$. Este texto siríaco, con cada una de las dinastías mencionadas, está preservado en distintos manuscritos publicados desde el siglo XIII en adelante ${ }^{3}$. TAKAHAsHI (2005: 292-293) cita los códices Vat. Sir. 166 [Scandar 24] (pt. 1, antes

1 Sobre las problemáticas en torno del título de la crónica, cfr. Aigle (2005: 91).

2 Para una síntesis del contenido de Chronicon ecclesiasticum, cfr. Вrocк (1976: 22-23; 1979: 19-21); TAKAHASHI (2005: 74-75).

3 Algunos manuscritos transmitieron el Chronicon syriacum junto con el Chronicon ecclesiasticum del mismo autor. Estas obras fueron separadas en época moderna. Cfr. Brock (1979: 19); TAKAHASHI (2005: 74-75).

4 Takahashi (2005) publicó una bibliografía exhaustiva de los títulos de manuscritos, extractos, traducciones y revisiones de la obra completa de Bar Hebraeus. Cfr. MAZZOLA (2018: 73-74). del año 1356/57) $)^{5}$ Berol Sachau 210 [237 Sachau] (siglo XIV), JerM 211 Dolabani (ca. 1491/2), Bodl. Hunt 1 [122 PS, 25 Uri, 5752 Madan]/8 (ca. 1498), JerM 36 Baumstark (antes del año 1570/1), Laur 136 [Palat o 118 Assemani] (1578/9), y Vat 383-388 [Assemani 126-131] (siglo XVIII). También nombra los manuscritos Bodl. Hunt 52 (siglo XIV), Vat 167 [Prop. Fid. 14] (no datado), Dair alZa farân (no datado), Damascus Syr. Orth. (no datado), y Kharput (no datado $)^{6}$. Aunque no todos estos escritos recibieron igual atención. Solo Bodleiani despertó mayor interés entre los eruditos modernos. Fue editado por primera vez en el año 1789 por BRUnS y KIRSH (Leipzig). Esta edición estuvo basada principalmente en el manuscrito Bodl. Hunt 52, y fue utilizada más tarde por BEDJAN (Paris, 1890), quien se apoyó en las contribuciones de revisores como BERNSTEIN y otros, y en manuscritos no especificados, para corregir el texto de Bruns y Kirsh (Takahashi 2005: 277). Tiempo después, Budge editó un facsimil del Bodl. Hunt 52

5 Este códice es el más antiguo. Cfr. Brock (1979: 19-20). Contiene el Chronicon civil ("L. Chronicorum") y Chronicon ecclesiasticum. Según TaKahashi (2005: 292), se encuentra formado por 421 folios: "1668 A.gr. [= anno Graecomm], with later additions. Fol. 1-243: Chron. civ. with continuation to 1600 A.Gr. [1288/9]; fol. 244-: Chron. eccl. I, to 1804 [1492/3]; fol. 353-421: II, to 1801 [1495/6]".

6 Takahashi (2005: 292-294) enumera otros manuscritos que contienen solo extractos, i.e. Berol. Sachau 315 [167 Sachau] (1480/1); Ming 474 (ca. 1560); Tübingen Ma. V. 1 [54 Assfalg]; etc. 
(Oxford, 1932) a partir de la edición de Bedjan ${ }^{7}$. Su libro contiene tanto la traducción (vol. I) como el texto siríaco en su lengua original (vol. II). Este trabajo fue la base del Chronicon Syriacum editado nuevamente en el año 1987 por ÇıçEK, quien presenta una copia de la edición de BEDJAN, además de una comparación de esta edición con el texto de BUDGE.

Bar Hebraeus también escribió una crónica árabe (Historia Dynasticarum, K. d-Maktbānūt arabāȳā, mukhtasar ta'rīkh al-duwal $=$ " $L$. Chronicorum, Arabicè"). Esta contraparte del texto siríaco sigue el mismo patrón que el Chronicon Syriacum; se divide en diez dinastías, excepto por la omisión de la quinta, concentrada en los medos. El texto completo fue conocido a través de treinta y nueve manuscritos, incluidos extractos y fragmentos, también enumerados por TAKAHASHI (2005: 309-313). Entre estos documentos figuran los códices Paris arab 6501 [olim Seert 129] (año 1358), Paris arab 296 [Colbert 4148; 738.3 Regius; A.F. 137] (siglo XIV), Laur 93 [Palat o 117 Assemani] (siglo XIV), Leiden 985 Warner [760 Dozy, 839 Goeje-Juynboll] (ca. siglo XIII-XIV), Leiden 533 Warner [759 Dozy, 838 Goeje-Juynboll] (ca. 1400), y BritLib Or 3009 [32 Rieu Suppl., Kremer 6] (ca. siglo XV). La primera edición de Historia Dynas-

7 Para leer las correcciones sobre la traducción de Budge, cfr. Honigmann (1934: 273-283); KuRdian (1938: 431).

8 Sobre el título árabe de este trabajo, cfr. SAMir (1980b: 142-144); ConRAD (1994: 319-378). ticarum está datada en el año 1663 y pertenece a Pocockius (Oxford), quien acompaña el texto árabe con una traducción latina y un Supplementum Historiae Dynastiarum (... $)^{9}$. Esta publicación de Pocockius fue seguida por una nueva edición realizada por SĀLhĀNì (Beirut, 1890) ${ }^{10}$. Su trabajo y el de Pocockius consiguieron una amplia aceptación por parte de los estudiosos modernos que editaron otra vez el texto árabe a partir de sus valiosos aportes. Historia Dynasticarum recibió de esta manera una tercera edición de la mano de $\mathrm{AL}$ Mansūr (Beirut, 1997). Su texto no agrega modificaciones al texto árabe de la publicación de SĀLHĀNī, solo ocasionales notas al pie sumadas a las existentes en la edición de $1890^{11}$.

De acuerdo con la cantidad de manuscritos que copian partes o las obras practicamente completas de Bar Hebraeus, entendemos que Chro-

9 Según Takahashi (2005: 301), el mismo autor publica otra edición en el año 1672 (ibid., "non vidi") bajo el título Historia Orientalis authore Gregorio Abul Pharagio (Oxford). Cfr. Fiey (1986: 303).

10 Nallino (1931: 308, nota 3) observa que al menos dos pasajes presentes en la edición de Pocockius fueron eliminados de la edición de SÂLHÂNî, presumiblemente debido "(fear of) Ottoman censorship", como afirma TAKAHASHI (2005: 302). Cfr. ed. Pocockius 165, 12-166, 10; 180, 16181, 1; FÜCK (1955: 88, nota 241; 297 nota 717).

11 Fuera del texto árabe elaborado por Bar Hebraeus, el Chronicon Syriacum tuvo continuaciones en producciones de autores posteriores. Brock (1979: 19-20) y TAKAHASHI (2005: 75) afirman que el primero de estos continuadores fue el hermano de Bar Hebraeus, llamado Barsawmā. 
nicon Syriacum e Historia Dynasticarum han sido de valor sustancial para conocer la historia secular del mundo conocido por Bar Hebraeus hasta el siglo XIII. Tanto un texto como el otro funciona como obra autónoma con importante información sobre los acontecimientos sucedidos durante la época antigua, tardoantigua y medieval. Por esta razón, la descripción frecuente de la Historia Dynasticarum simplemente como una traducción o un resumen de Chronicon Syriacum es engañosa, dado que existen grandes diferencias entre las dos obras, e Historia Dynasticarum incluye una cantidad significativa de material adicional ausente en el texto siríaco $^{12}$. Así ocurre con la embajada a Gayo y Filón de Alejandría. El texto siríaco y el árabe relatan este evento y los acontecimientos en torno a la audiencia ante el emperador romano y Filón con noticias que difieren en datos precisos, que habrían sido extraídos por Bar Hebraeus de las obras de varios autores que transmitieron información sobre aquel suceso, principalmente griegos, latinos y siríacos, como demostraremos en nuestro estudio. Este está dividido en dos partes. En la primera presentaremos las evidencias para la embajada a Gayo y Filón. Comenzaremos con un rastreo de las referencias vinculadas con este evento en las fuentes griegas, latinas y siríacas, en especial Contra Flaco y Embajada a Gayo de Filón,

12 Cfr. Takahashi (2005: 75). Sobre la relación entre Chronicon Syriacum e Historia Dynasticarum, cfr. TeUle (1996); TAKAHASHI (2001).
Antigüedades judías de Josefo, Historia eclesiástica de Eusebio, Chronicon de Jerónimo y Chronicon de Miguel el Sirio. Los datos transmitidos por cada una de estas fuentes serán puestos en comparación finalmente con las noticias anotadas en las crónicas de Bar Hebraeus. En la segunda parte realizaremos una síntesis de la estructura de estas crónicas siríaca y árabe, y presentaremos su correspondiente traducción y notas.

\section{La embajada a Gayo en las fuentes griega y latina}

$\mathrm{L}$ as noticias sobre los sucesos ocurridos antes y durante la embajada de los judíos de Alejandría ante Gayo fueron comentadas por primera vez en los tratados históricos Contra Flaco y Embajada a Gayo, escritos por Filón de Alejandría (ca. 20 a.C. -50 d.C. $)^{13}$, publicados después del año 41 d.C. y considerados $^{14}$ como partes de una sección más amplia. Esta conjetura está basada en que Filón abre Contra Flaco con un resumen de las acciones del prefecto y cónsul romano Lucio Elio Sejano (ibid., 1$)^{15}$, fallecido en el año 31 , que habría sido probablemen-

13 Cfr. Torallas Tovar (2009: 181). Sobre la vida de Filón, cfr. TERIAN (1981: 31); Martín (OCFA I 2009: 10-15, 35 y 37).

14 Cfr. SANdmel (1981: 3-46).

15 Lucio Elio Sejano (20 a.C.-31 d.C.) fue un político y militar romano, amigo y confidente del segundo emperador, Tiberio. En el año 30, fue nombrado cónsul, y en el 31, fue acusado de planear el asesinato de Gayo y ajusticiado. 
te el tema del fragmento perdido ${ }^{16}$. Si bien pasan siete años desde la muerte del cónsul hasta los hechos del año 38 relatados por Filón, en el inicio del tratado acusa a Sejano de haber ideado un plan de exterminio contra los judíos ${ }^{17}$. Semejante acusación funciona como principio argumentativo del asunto desarrollado en Contra Flaco, cuyo contenido se conserva prácticamente completo. Relata el ataque contra los judíos de Alejandría ordenado por el prefecto romano Aulo Avilio Flaco en el 38, luego del censo poblacional del $33 / 34^{18}$, del complot contra los judíos planificado por los líderes del movimiento griego alejandrino y Flaco entre los años 37 y $38^{19}$ (ibid., 21-24; P. Oxy. 1089), y de la promul-

16 Incluso hay una alusión a un texto de Contra Flaco de Filón en Juan Damasceno que, debido a su falta de correspondencia con el texto conocido, se supone que pudo haber pertenecido a la parte perdida. Cfr. Royse (1991).

17 La misma acusación es repetida por Filón en Embajada a Gayo 159-160. Esta maquinación de Sejano solo es registrada en Historia eclesiástica 2. 5. 7 de Eusebio, que parece depender de Filón. Cfr. Smallwood (1961: 243-244); VAN DER HORST (2003: 89-91).

18 El censo fue realizado para conocer las nuevas listas de los que estaban sujetos al pago

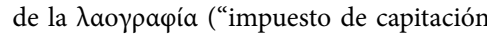
exigido a todos los no residentes [de Alejandría]"). Cfr. Bagnall y Frier (1994: 7); Druille (2015: 132). Sobre la existencia de la $\lambda \alpha$ oүo $\alpha \varphi$ í $\alpha$ en la documentación papirológica de Egipto ptolemaico, cfr. $P$. Ryl. 4. 667 (siglo II a.C.); Taubenschlag (1955: 612 y nota 15).

19 Los principales líderes del movimiento griego fueron Isidoro, Dionisio y Lampón. Cfr. Tcherikover y Fuks (1960: 66); DRUILLE (2017: 76-91). gación de los tres edictos del 38 (ibid., 53-55), mediante los cuales Flaco de-

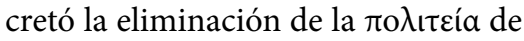
la comunidad judía ${ }^{20}$, la declaración de su extranjería ${ }^{21}$, y la licencia oficial para "saquear a los judíos"22 ( $\pi 0 Q-$

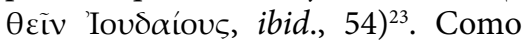
resultado de esta persecución y reconocimiento oficial de extranjería, que habría provocado la anulación de los derechos especiales concedidos a los judíos para la práctica de las costumbres ancestrales y las prerrogativas cívicas derivadas del derecho de residencia legal ${ }^{24}$, los líderes de las facciones judía y griega resolvieron enviar delegaciones a Roma durante

20 Cfr. Contra Flaco 141. Sobre los distintos

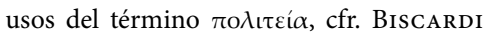
(1983-19-26).

21 Filón no aporta algún testimonio que facilite precisar el origen político de la segunda disposición de Flaco, aunque ciertos indicios presentes en $P$. Yale II, 107 podrían estar vinculados con su edicto. Cfr. col. III, 11 . 9 y 21; Druille (2019).

22 Las traducciones al castellano de las palabras o fragmentos griegos y latinos fueron realizadas a partir de su lengua original por Paola Druille, quien basó su trabajo en las ediciones detalladas en la sección bibliográfica.

23 Esta licencia oficial incluía la habilitación para asaltar sus sinagogas y la expropiación de sus viviendas. Los judíos fueron obligados a habitar una pequeña parte de dos de los cinco distritos de Alejandría (Contra Flaco 55) ocupados por sus juderías. Cfr. Estrabón, citado por Josefo en Antigüedades judías 14. 117; Josefo, Contra Apión 2. 34-35.

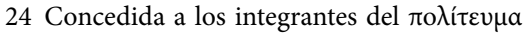
judío por los gobernantes anteriores a Gayo. Cfr. Druille (2015: 135; 2019). 
el invierno del año $38 / 39^{25}$, con el fin de pedir una audiencia con el emperador Gayo. La embajada judía buscaba la devolución de las exenciones anuladas por Flaco, mientras que la griega tenía como objetivo persuadir a Gayo para evitar que las prerrogativas eliminadas por el prefecto fueran recuperadas por los judíos, según lo expone Filón en Embajada a Gayo.

Filón cuenta aquí las calamidades vividas por los judíos en tiempos de Gayo y la demencia del emperador al autoproclamarse dios, al mismo tiempo que narra las circunstancias atravesadas por la embajada judía en su encuentro con Gayo. Refiere las dos solicitudes presentadas por los miembros del consejo de ancianos ante el emperador en defensa de las leyes patrias -la restitución del derecho a practicar la religión libremente (ibid., 191), y el restablecimiento de los dere-

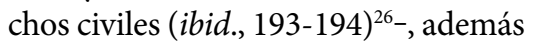
de la intención de Gayo de introducir su propia estatua en el Templo de Jerusalén (ibid., 184-198), la audiencia que el emperador mantuvo con las delegaciones judías y griegas en los

25 Para la datación de la embajada, cfr. SMALLWOOD (1961: 47-50; 1976: 242-246). Sobre la teoría de la partida de la embajada en el invierno del año 38/39, cfr. SiJPESTEIJN (1964: 87-96); MorRIS (III 1987: 816, nota 15).

26 En el último año de Calígula tuvo un lugar una serie de desórdenes y ataques al Templo de Jerusalén referidos por Filón en Embajada a Gayo 184-384, Flavio Josefo en sus dos obras históricas (Antigüedades judías 18. 261-310; La guerra de los judíos 2. 184-203) y Tácito (Historia 5. 9). Las narraciones son contradictorias en muchos de los detalles, pero Filón parece ser la fuente más fiable en cuanto a la cronología de los hechos. jardines de Lamia y Mecenas (ibid., 349-367), el desprecio de Gayo por las costumbres ancestrales de los judíos y su reproche por la negativa judía de ofrecer sacrificios a su persona (ibid.). Cada uno de estos hechos es narrado con gran detalle en el tratado filónico, sin dejar de lado ninguna información relevante. Sin embargo, pese al realismo de sus testimonios, Filón no brinda datos certeros sobre la composición de la embajada. Solo señala que, junto con los miembros de la delegación judía, fueron enviados líderes griegos contrarios a los judíos de la ciudad portuaria como delegados con la misión de impedir la anulación de las disposiciones de Flaco (ibid., 172, 354). En cuanto a la embajada judía, indica que estaba formada "por cinco emba-

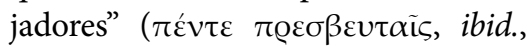
370) de la $\gamma \varepsilon$ gov $\sigma i ́ \alpha$ judía (ibid., 1$)^{27}$, entre los que se incluye el mismo Filón (ibid., 182), aunque no menciona los nombres del resto de los integrantes. Tampoco deja testimonio del nombre del líder de la delegación. Dice simplemente que, antes de la audiencia final (ibid., 349-367), los embajadores judíos consiguieron un primer recibimiento por parte de Gayo en la llanu-

27 En el prólogo de Embajada a Gayo (1), Fi-

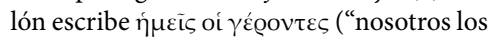
ancianos”). La primera persona del plural para mencionar el grupo de delegados judíos es utilizada también en Embajada a Gayo 187; 352; 359; etc. Este dato parece informar sobre la jerarquía de los embajadores judíos, que habrían sido cinco en total (ibid., 370). Según Morris (1987: 816, nota 15), el hermano de Filón, llamado Alejandro, y su sobrino, Tiberio Julio Alejandro, podrían haber estado entre los cinco miembros. 
ra a orillas del Tíber (ibid., 180), que mereció la alegría de los embajadores judíos, a excepción del propio Filón, quien expresa (ibid., 182):

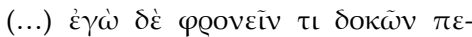

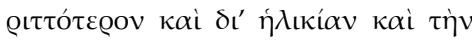

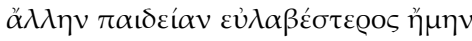

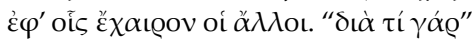

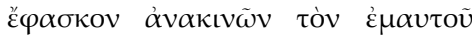

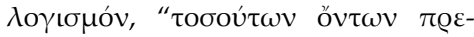

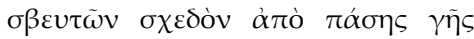

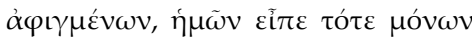

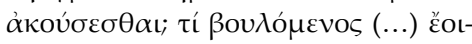
$\kappa \varepsilon \tau \tilde{\eta} \tau \tilde{\omega} \nu \alpha \ddot{\alpha} \lambda \lambda \omega \nu \mathrm{A} \lambda \varepsilon \dot{\xi} \alpha \nu \delta \varrho \varepsilon ́ \omega \nu \mid \mu \varepsilon-$

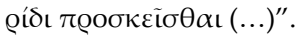

(...) yo, que considero que tengo una mayor prudencia, por mi edad y mi educación, estaba más precavido con respecto a aquello por lo que los otros se alegraban tanto. “¿Por qué”, me decía, alertando a mí propia razón, "habiendo tantos embajadores venidos de casi todos los lugares de la tierra, ahora dice que sólo a nosotros nos escuchará personalmente? ¿Qué es lo que quiere? (...) parece estar favoreciendo a la otra parte de los alejandrinos (...)".

Según Torallas Tovar (2009: 269, nota 142), este pasaje contiene noticias acerca de la composición jerárquica de la embajada judía. Considera

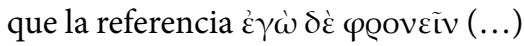

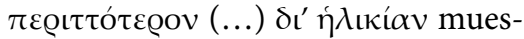
tra que "Filón es el mayor en edad de la representación de los judíos en la embajada al emperador" (ibid.) $)^{28}$, y el

28 Filón menciona su edad una vez más en el prólogo de Embajada a Gayo, cuando se

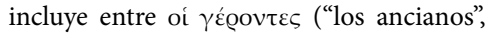
1). Cfr. Morris (1987: 816, nota 15). So- líder de la delegación peticionaria de sus derechos. Pero esta información no es concedida por el alejandrino. Surge décadas más en Antigüedades judías 18. 257-260 del historiador judío Flavio Josefo (ca. 37-100). Después de relatar el enfrentamiento entre los judíos y los griegos ocurrido en el 38, Josefo agrega noticias sobre la composición jerárquica de las embajadas, inexistente en el tratado de Filón:

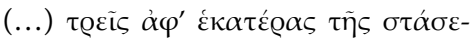

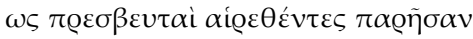

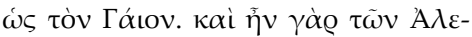

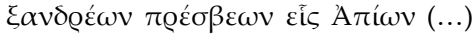

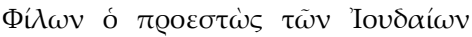

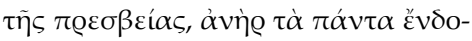

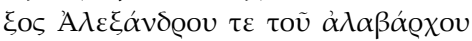

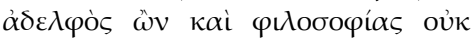

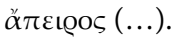

(...) cada bando eligió tres embajadores, que se presentaron ante Gayo. Uno de los embajadores alejandrinos era Apión (...) [y el otro era] Filón, quien presidía la delegación judía, hombre ilustre por todos los conceptos, y que era hermano del alabarca Alejandro y no inexperto en filosofía (...).

La referencia de Josefo (Antigüedades judías 18. 257) indica que una y otra embajada, la griega y la judía, se componían de tres miembros por facción, y no cinco, como indica Filón para el grupo judío. También sugiere que la delegación griega estaba encabezada

bre Filón como una figura políticamente activa, cfr. Goodenough (1926: 77-79); MORRIS (ibid., p. 818, nota 23; también pp. 844, 849-850). 
por Apión, y la judía por Filón, sobre quien agrega datos biográficos rela-

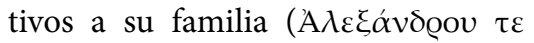

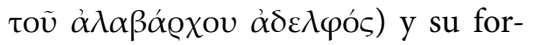
mación filosófica. No obstante, pese a que la breve descripción de Josefo "is the only reference from a near contemporary" (Morris III/2 1987: 814, nota 12), sus testimonios solo son anecdóticos frente a la carencia de otras fuentes que permitan corroborar los nombres de los integrantes de ambas delegaciones. Josefo introduce los nombres de Filón como líder de la embajada a Gayo (Antigüedades judías 18. 259), y de Apión a cargo de la delegación griega, sin ninguna información explícita acerca de las circunstancias de la embajada, ni otros indicios que demuestren la fuente de referencia usada para su relato. El testimonio de Josefo sobre el liderazgo de Filón y Apión parece formar parte de una interpretación personal del autor, que tuvo una vasta aceptación entre los autores cristianos posteriores ocupados en transmitir su noticia sin agregar mayores cambios.

Eusebio (ca. 260/263-339), obispo de Cesarea hasta el año 339, no solo reproduce el relato de Josefo en Historia Eclesiástica y Chronicon, sino que refleja un profundo conocimiento de la vida y escritos de Filón, como muestra en Historia Eclesiástica. Primero sostiene que, en el tiempo de Tiberio, "Filón era conocido por muchos"

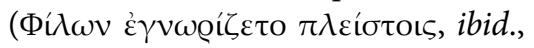
2. 4. 2), y que "descendía de una familia hebrea (...) en Alejandría” (

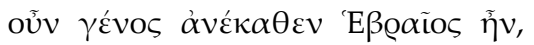
(...) $\varepsilon \pi^{\prime} A \lambda \varepsilon \xi \alpha v \delta \varrho \varepsilon i ́ \alpha \varsigma$, ibid.). Segun- do enumera una serie de títulos de tratados que atribuye a Filón (Historia Eclesiástica 2.5.1 y 2.18.1-8). Dentro de esta lista, el obispo incorpora los cinco libros ${ }^{29}$ que contienen la iniciativa de Sejano de acabar por completo con judíos, el crimen perpetrado contra Jesús en Judea bajo el gobierno de Pilato, las calamidades de los judíos en tiempos de Gayo, la megalomanía del emperador, su autoproclamación divina, los atropellos cometidos contra los judíos y "la embajada que a [Filón] le fue confiada en la ciudad de Roma en favor de sus congéneres de

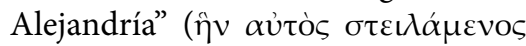

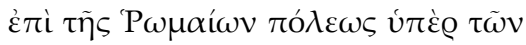

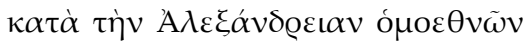

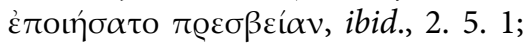
también 2. 5. 4). Aquí introduce el relato de Josefo sobre el liderazgo de Filón en la delegación judía ${ }^{30}$ y sobre Apión como parte de la griega, sin

29 MORRIs (1987: 861, nota 23) considera que el libro I presumiblemente contenía una introducción general; el libro II, las persecuciones en tiempos de Tiberio, Sejano en Roma y Pilato en Judea, junto con el final violento de estos dos enemigos de los judíos; el libro III, Contra Flaco, conservado prácticamente completo; el libro IV, Embajada a Gayo; y el libro V habría tratado sobre la caída de Gayo y el giro favorable a favor de los judíos. Solamente dos se han conservado: Contra Flaco y Embajada a Gayo. La clasificación de las obras de Filón ha sido objeto de incesantes discusiones, ya desde antes de la aparición de la obra de L. Louis Massebieau (Le classement des oeuvres de Philon, Paris, E. Loroux, 1889).

30 Eusebio asegura que "estos hechos los menciona (...) Josefo en el libro dieciocho de

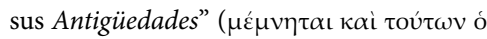

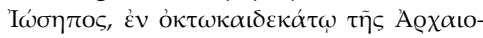

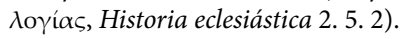


mencionar posición jerárquica alguna (ibid., 2. 5. 3). Tercero agrega que "Filón, en su obra Embajada, expone con todo pormenor y exactitud lo que él hizo por entonces (ó $\Phi \dot{\lambda} \lambda \omega \nu$ غ̇v $\tilde{\eta}$

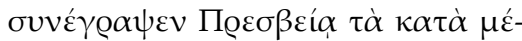

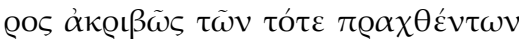
$\alpha \dot{v} \tau \tilde{\omega} \delta \eta \lambda$, que posiblemente alude al testimonio filónico inherente a la audiencia entre los delegados de la $\gamma \varepsilon$ govoía judía y Gayo en los jardines de Lamia y Mecenas (Filón, Embajada a Gayo 349-367). Por último, el obispo nombra nuevamente el tratado hitórico de Filón (Historia eclesiástica 2. 18. 8), y sostiene:

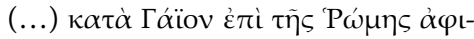

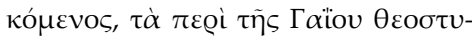

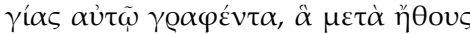

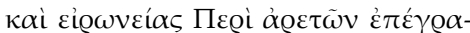

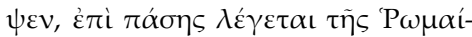

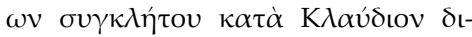

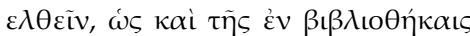

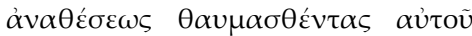

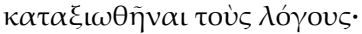

(...) luego llegó [Filón] a Roma en tiempos de Gayo, y se dice que sus escritos sobre la teofobia de Gayo, que tituló, con ingenio e ironía, Sobre las virtudes $^{31}$, los expuso delante del senado romano en pleno, en tiempos de Claudio, de modo que sus obras fueron muy admiradas y se las consideró dignas de ser colocadas en las bibliotecas.

A partir de este pasaje, Morris (III/2 1987: 863) elabora la siguiente conjetura. Defiende que la existencia de

31 Cfr. Historia eclesiástica 6. 3; 17. 3. dos trabajos filónicos con información diferente relativa al evento de la audiencia en Roma, uno de los cuales

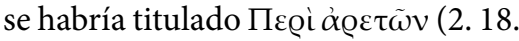

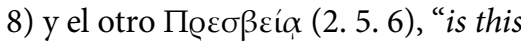
intrinsically improbable" (ibid.). De hecho, Eusebio menciona únicamente el último título en su catálogo principal de los trabajos de Filón (Historia eclesiástica 2. 18), cuando aclara que el alejandrino le dio el nombre de

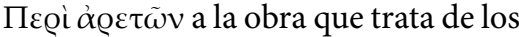
actos impíos de Gayo (2. 18. 8). Sin embargo, Runia (1993: 20-21) supone lo contrario. Estima que tanto Пe@i

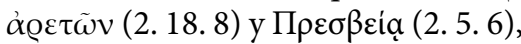
como el resto de los títulos enlistados por Eusebio en Historia Eclesiástica 2. 5. 6 y 2. 18. 1-8, refleja seguramente la posesión de la biblioteca episcopal de Cesarea, donde Eusebio fue obispo hasta su muerte en el 339 (ibid., pp. 20-21), y donde se conservaron sus propios escritos que habrían obtenido una amplia difusión después del siglo $\mathrm{IV}^{32}$, "como demuestran la abundancia y la calidad de los más antiguos manuscritos y versiones" (Velasco-

32 Según Runia (1993: 20-21), tiempo después de la muerte de Eusebio, Euzoios -obispo de Antioquía (ca. 360/61 d.C.) y de Cesarea (ca. 373/376-379)- habría transferido los escritos de Filón a códices, y de allí pasaron al dominio de la tradición bizantina que conservó los textos filónicos en unos sesenta y cinco manuscritos datados entre los siglos IX y XVII (ibid., p. 22). Sobre la tradición textual de los fragmentos de Filón encontrados en papiros, cfr. Jerónimo, De Viris Illustribus 113; RoBerTs (1963: 11-15); BARTHÉLEMY (1967: 59); Royse (1980: 156); Runia (1993: 22 ss.). 
Delgado 2008: 61) ${ }^{33}$. Su Historia eclesiástica consiguió una traducción siríaca contenida en el documento $\mathrm{S}$, conservado en el manuscrito de San Petersburgo ( $c a$. 462) y en el manuscrito del British Museum de Londres (ca. siglo VII), que habría permitido el traspaso de las referencias de Eusebio a la tradición siríaco-armenia ${ }^{34}$. El Chronicon ${ }^{35}$ de Eusebio ${ }^{36}$, en cambio, no se ha preservado en su lengua

33 Sobre la tradición manuscrita de Historia eclesiástica, cfr. SChwartz (1909: XVIIICCXV ss.); Mossay (1981: 222); VelasCo-Delgado (2008: 61 ss.).

34 Cfr. W. Wright y L. McLean (eds), The Ecclesiastical History de Eusebio en siríaco (California, 1898), con una colación de la versión armenia de A. Merx (p. XVIII, 418); Eb. Nestle (ed.), Die Kirchengeschichte de Eusebio en siríaco (Texte und Untersuchungen zur Geschichte der altkirchlichen Literatur, Leipzig, 1901, p. 296); también WitakowsKi (1999-2000: 427).

35 El género de la crónica tiene raíces precristianas, principalmente en la cronografía helenística. Cfr. Eratóstenes (ca. 194 a.C.), X primero en elaborar una crónica en época cristiana. Cfr. Historia eclesiástica 6. 7. Sexto Julio Africano de Palestina (ca. 160-

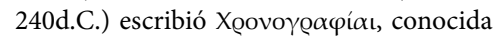
y usada por Eusebio. Cfr. Historia eclesiástica 1. 6. 2 y 7; 1. 7. 16; especialmente 6, 31 et passim; WitAKOWSKI (1999-2000: 421); Velasco-Delgado (2008: 20, 40).

36 El Chronicon de Eusebio estaba compuesto por dos partes: la cronografía y los cánones, de los cuales los últimos están en existencia en ambas traducciones, pero el primero solo en armenio. La cronografía presenta breves relatos de la historia de varios estados o naciones -caldeos, asirios, hebreos, egipcios, griegos y romanos-, junto con listas de gobernantes y datación cronológica, provistas por las fuentes que Eusebio tenía a su alcance, especialmente aquellas procedentes de cronógrafos anteriores y la griega original (WiTAKowski 19992000: 423). Solo se conserva fragmentado en una traducción armenia (anónima, ca. 600) y, especialmente, en el Chronicon de Jerónimo ${ }^{37}$ ( $c a$. 340-420), quien presenta los datos en torno a la embajada de manera segmentada, y en el siguiente orden: 1) "Sejano, el prefecto de Tiberio (...) insta con insistencia a que se destruya la nación judía. Filón recuerda esto en el libro Embajada II" (Sejanus praefectus Tiberii (...) instantissime cohortatur, ut gentem Judaeorum deleat: Philo meminit in libro Legationis II, 2050c, ed. Helm (1956), p. 258); 2) Tiberio decide publicar un edicto para amenazar de muerte a los acusadores de los cristianos (2050g, ibid., pp. 258-259), información derivada del Apologeticum de Tertuliano (ibid.); 3) luego de nombrar a Agripa

Biblia. La cronografía finaliza con las series regum. Los cánones se caracterizan por estar dispuestos en columnas verticales paralelas, presentando nombres de gobernantes de varios imperios, países o naciones y los años de sus gobiernos anotados verticalemnte uno debajo del otro. Cfr. J. KARst, Eusebius, Die Chronik, aus dem Armenischen übers., mit textkritischem Commentar hrsg. (Leipzig, 1911), pp. 1-155. Algunos fragmentos de la cronografía están también en griego. Cfr. J. A. Cramer (ed.), Anecdota Graeca e codd. Manuscriptis Bibliothecae Regiae Parisiensis, vol. 2 (Oxford, 1839; reimp. Hildesheim, 1967), pp. 115-163. Para un estudio completo del Chronicon de Eusebio, cfr. WITAKOWSKI (1999-2000: 419437).

37 La traducción de Jerónimo es considerada como aquella que preserva más verdaderamente el formato original de Eusebio que la armenia, pero contiene solo la segunda parte del trabajo de Eusebio. Cfr. WITAKOWSKI (1999-2000: 423). 
rey de Judea, Gayo se declara un dios (2050c-d, ibid., p. 259), mientras "Flaco Avilio, prefecto de Egipto, [junto con el pueblo de Alejandría], oprime a los judíos con muchas calamidades" (Flaccus Avilius praefectus Aegypti, multis Judaeos calamitatibus premit, 2050e, ibid.), y contamina las sinagogas con imágenes, estatuas, altares y víctimas de sacrificio (ibid.); 4) "Filón declara en el libro llamado Contra Flaco que estuvo presente en todas estas cosas, por lo que incluso él mismo había emprendido una delegación a Gayo" (Refert Philo in eo libro, qui Flaccus inscribitur, haec omnia se praesente gesta, ob quae etiam legationem ad Gaium ipse susceperat, ibid.). Aparte de estos datos, la traducción de Jerónimo no brinda noticias sobre la composición jerárquica de la embajada judía; agrega únicamente que Filón y Josefo escribieron acerca de los acontecimientos ocurridos en el 38 (2050e, ibid., p. 260), y continua con otras referencias posteriores a la audiencia, donde aparece la decisión de Claudio de enviar a Félix a Judea para que asuma como procurador (2060c, ibid., p. 263).

Es difícil conocer la influencia de la traducción latina de Jerónimo sobre los historiadores tardíos, no así del Chronicon de Eusebio. Habría sido traducido al siríaco, de la misma manera que la Historia eclesiástica, pero desafortunadamente no ha sido preservada en una tradición manuscrita separada $^{38}$, y todavía se desconocen

38 Sobre la tradición siríaca del Chronicon de Eusebio, cfr. Keseling (1926-1927). datos sobre la época de su traducción y los autores ocupados en esta tarea (Keseling I 1926-1927: 27 ss.). Sin embargo, "we are relatively knowledgeable about this translation as later chroniclers used it extensively" (WITAKowski 1999-2000: 427); los cronistas posteriores la usaron ampliamente, resguardando no solo una gran parte de su texto sino también su forma, permitiendo que el género de la crónica se implante en la historiografía siríaca. Jacobo de Edesa, Miguel el Sirio y Bar Hebraeus, entre otros cronistas, citan referencias que Eusebio anota en su Chronicon y en su Historia eclesiástica. Si bien hay discrepancias en lo que respecta a las fechas, y en los relatos de las historias, que parecen haber sido abreviados por los cronistas siríacos, las referencias históricas dadas a conocer por las obras de Eusebio se convirtieron en la fuente de consulta más importante de los cronistas medievales que reproducen, con ciertas alteraciones, la ordenación y datación de los acontecimientos sucedidos durante los años 38-39/40 d.C.

\section{La embajada a Gayo en las fuentes siríacas}

L as noticias sobre la embajada a Gayo y Filón de Alejandría habrían llegado a la tradición siríaca de la mano de Eusebio. Su Historia eclesiástica habría recibido una traducción siríaca, según se explicó más arriba, y resulta tentador afirmar que su Chronicon habría conseguido un destino similar. Sin 
embargo, ninguna fuente confirma esta tesis de manera fehaciente. Según Witakowski (1999-2000: 427), 'Abhdisho', el metropolitano sirio de Nisibis de la Iglesia de Oriente ${ }^{39}$ (siglo XIV) y autor de la primera historia de la literatura siríaca, conocida como El Catálogo, escribió que la traducción del Chronicon fue realizada por Simeon de Beth Garmay, un siríaco que probablemente vivió en el siglo $\mathrm{VI}^{40}$. Otros testimonios intentan demostrar que semejante tarea fue efectuada por Jacobo de Edesa (ca. 640-708), quien habría redactado un Chronicon a modo de continuación de la crónica de Eusebio (Brooks 1899: 263; Witakowski 2008: 29). Esta tesis, junto con el título de esta obra, es transmitida por Miguel el Sirio en su Chronicon (ca. 1199), y está basada en el trabajo historiográfico perdido de Teodosio de Edesa (siglo IX). El Chronicon de Miguel informa sobre la traducción del griego al siríaco de la historia de Eusebio realizada por Jacobo (Chronicon 7. 128, ed. Снавот $)^{41}$, cuya crónica sobre-

39 Según Ubierna y Francisco (2018: 50), “(...) La Iglesia de Oriente conformó el grupo cristiano mayoritario en el Imperio persa (Sasánida) y posteriormente después de las conquistas árabes lo siguió siendo en los territorios al Este del Éufrates" (el subrayado no es nuestro).

40 Cfr. Assemani (1725: 633); Witakowski 1999-2000: 427).

41 Cfr. Witakowski (2008: 32). La obra no preservada del historiador Teodosio de Edesa fue utilizada por el Patriarca Dionisio de Tel-Mahre (818-847), cuyo texto fue empleado por Miguel el Sirio en Chronicon (5. 83, еd. СНАвот). vivió de manera tan fragmentada ${ }^{42}$ que impide confirmar el argumento de Miguel. Los pasajes existentes empiezan con Constantino (ca. 306$337)^{43}$ y terminan con el año 306 de la era de Jacobo que, conforme a los datos del propio autor, es el vigésimo primer año de Heraclio I (ca. 630), el segundo de Ardashir III de Persia (ca. 629) y el tercero del califa Abū Bakr (ca. 634). Toda la historia anterior a Constantino se ha perdido ${ }^{44}$.

El Chronicon de Miguel el Sirio, en cambio, se encuentra prácticamente completo. Miguel fue patriarca de la Iglesia Siriano-Ortodoxa ${ }^{45}$ desde el año 1166 hasta su muerte en el 1199. Alrededor de esta época habría escrito su historia secular en veintiún libros, desde la creación hasta el año $1194 / 5^{46}$, que según indica el propio autor depende casi exclusivamente de

42 Cfr. Brooks, Guidi, y Chaвot (1905: 261-330).

43 Cfr. Brooks (1899: 262-263).

44 Cfr. Witakowski (2008: 38), quien asegura que "no agreement has been reached as to whether Jacob's work originally included pre-Constantinian material” (ibid., p. 41).

45 También denominada "jacobita", como aseguran Ubierna y Francisco (2018: 49), "en recuerdo de Jacobo Baradeo $(\uparrow 578)$, reorganizador de la Iglesia miafisita de Siria en el siglo VI".

46 Según Brock (1976: 21), esta es la crónica siríaca más completa e importante. Un manuscrito fechado en 1598 contiene el texto siríaco de este trabajo masivo y fue descubierto en 1889 en Urfa (Edesa). Es una transcripción en facsímil que publicó Снавот, con una traducción al francés y un índice de nombres. También existe una traducción al árabe de la crónica de Miguel. Cfr. Снавот (I 1899: XLII-L), quien asegura que esta versión habría sido hecha a 
los trabajos de Jacobo de Edesa (11. 450 y 452 , ed. СНавот; WitakowsKI 2008: 43). Sin embargo, en el Prefacio de su Chronicon, conservado en una traducción armenia ${ }^{47}$, enumera el nombre de Eusebio de Cesarea junto con el de Jacobo de Edesa dentro de una larga lista de cronistas anteriores a su obra -Sexto Julio Africano, Sócrates el Escolástico, entre otros. De acuerdo con lo explicado más arriba, frente a la falta de pruebas que permitan acreditar la influencia de Jacobo sobre la historia anterior a Constantino, Eusebio gana una atención especial para nuestro estudio. Los datos relacionados con Filón y la embajada a Gayo registrados en su Historia eclesiástica y su Chronicon, son reproducidos con modificaciones en el sexto libro de la crónica de Miguel. Primero son relatados los sucesos ocurridos durante el Imperio de Tiberio (6. 9496, ed. Снавот): 1) la muerte, resurrección y ascenso de Cristo, incluida la orden de Pilato de erigir la imagen

partir del manuscrito de Urfa. Cfr. Brock (ibid., p. 22, nota 6).

47 La versión armenia está abreviada y datada en el año 1248. Cfr. Снавот (ibid., pp. L-LI); F. Haase, "Die armenische Rezension der syrischen Chronik Michaels des Grossen", OrChr II, 5 (1915), pp. 60-82, 271-284. Hay una traducción francesa de V. Langlois, Chronique de Michel le Grand, traduite pour la première fois sur la version arménienne du prête Ishok (Venice, 1866), y otra de E. Dulaurier in JA 4 ser. XII (1848), pp. 81-334, y XIII (1849), pp. 315-376. Cfr. BRock (ibid., p. 22, nota 7); también el trabajo completo de A. B. Schmidt, "Die Zweifache Armenische Rezension der syrischen Chronik Michaels des Großen", Le Muséon 109 (1996), pp. 299-319. del César en el Templo, y el temor sentido por los sacerdotes reunidos en ese recinto, luego de escuchar una voz desde el centro del santuario en el día de Pentecostés; 2) el testimonio narrado por Filón en el segundo libro no conservado de su serie histórica, donde cuenta el plan de destrucción contra los judíos ideado por el prefecto romano Sejano; 3) el informe enviado por Abgar de Edesa a Tiberio sobre las afrentas sufridas por Cristo a causa de los judíos y, seguidamente, la decisión de Tiberio de vengarse de esa nación; y 4) la muerte de Tiberio, el exilio de Herodes y Herodías y su ejecución. Segundo son expuestos los hechos acaecidos en el Imperio de Gayo: 1) la proclamación de Agripa como rey de los judíos; 2) el nombramiento del prefecto Flaco como gobernador de Egipto, donde oprime a los judíos durante siete años, y llena sus altares y sinagogas con sacrificios; 3) el envío de la embajada judía liderada por Filón para solicitar audiencia con Gayo; 4) la erección de estatuas en los templos y en las sinagogas de los judíos ordenada por Gayo a Petronio, prefecto de Siria, y el cumplimiento de la palabra de Daniel acerca de la señal de abominación en lugar santo. Tercero son presentadas las circunstancias acontecidas en el Imperio de Claudio: 1) la llegada de Agripa a Cesarea, y su orden de programar fiestas y espectáculos en honor a César, y la capa tejida de plata vestida por Agripa durante el segundo día de celebración, por la cual es llamado dios e inmortal por sus aduladores; herida y muerte de Agripa; 2) el envío 
de Félix como procurador de Samaria y Galilea. Finalizado este último relato, Miguel continúa con la enumeración de otros hechos históricos; entre estos se pueden leer referencias vinculadas exclusivamente con Filón, como la lista de tratados atribuidos al alejandrino, dispuesta de una manera similar a la implementada por Eusebio en su Historia eclesiástica:

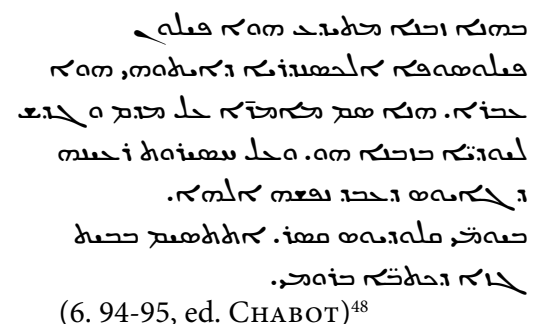

(...) floreció [durante el imperio de Tiberio] el filósofo Filón de Alejandría, que era hebreo. Compuso tratados sobre todo lo que les sucedió a los judíos en ese momento; sobre la locura de Gayo que se convirtió en dios (...) En la época de Claudio César [sus obras] fueron colocadas en los archivos públicos de Roma.

Miguel menciona más de diez textos de Filón, y las temáticas contenidas en cada uno. También aporta información de gran validez histórica relativa a la conservación del corpus filónico cuando asegura que, en el imperio de Claudio, la producción de Filón fue depositada en los archi-

48 Las traducciones al castellano de los fragmentos siríacos fueron realizadas a partir de su lengua original por Daniel Asade, quien basó su trabajo en las ediciones detalladas en la sección bibliográfica. vos públicos de Roma. Este testimonio se une cronológicamente a las noticias existentes sobre la historia de los escritos de Filón. De acuerdo con Runia (1993: 22-23), uno de los primeros autores tardoantiguos que atestigua una profunda dependencia de los tratados filónicos es Orígenes (ca. 185-254), quien habría guardado copias de la mayor parte de los trabajos de Filón en su biblioteca privada $^{49}$, llevada consigo durante su traslado de Alejandría a Cesarea en el año $233^{50}$. Hacia el final del siglo, su legado habría pasado al cuidado de Pámfilo, quien catalogó todo el material y lo preservó en buenas condiciones en la librería de la escuela episcopal. Su labor habría sido asistida por Eusebio, quien aporta más datos para la reconstrucción del proceso de transmisión de la producción de Filón antes de Orígenes. El obispo de Cesarea menciona que los escritos

49 Según Runia (1993: 22-23), “by the time that Origen took his copies to Caesarea nearly two centuries had passed since Philo's death. The first Church father whom we know to have made extensive use of Philo based on direct reading was Clement of Alexandria". Clemente fue una influencia formativa en Orígenes, y ambos trabajaron en el mismo entorno llamado escuela catequética de Alejandría, establecida alrededor del año 150 por Panteno. De acuerdo con BARThélemy (1967: 60), la escuela de Alejandría habría conservado los escritos de Filón después de la revuelta de los años 115-117.

50 Sin embargo, copias de los escritos de Filón continuaron circulando por varios siglos en Alejandría. Cfr. Runia (1993: 23), quien asegura que en el siglo IV las copias de Filón fueron ampliamente usadas por Didimo el Ciego. 
de Filón fueron expuestos ante el senado romano en tiempos de Claudio, "de modo que sus obras fueron muy admiradas y se las consideró dignas de ser colocadas en las bibliotecas"

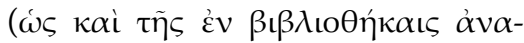
$\theta \varepsilon \dot{\sigma} \sigma \varepsilon \omega \varsigma$ $\theta \alpha v \mu \alpha \sigma \theta \varepsilon \dot{v} v \tau \alpha \varsigma \alpha \hat{v} \tau \bar{v} \kappa \alpha-$

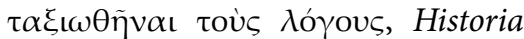
eclesiástica 2. 18. 8). Si bien es posible que las librerías referidas por Eusebio estén ubicadas en Roma, como afirma Runia (1993: 26), ningún dato en su obra permite confirmar esta tesis. La información aportada por Miguel, entonces, resulta doblemente importante. Por un lado, y dado el conocimiento sobre las temáticas de los tratados filónicos, Miguel habría estado en contacto con las obras de Filón o habría copiado referencias transmitidas por un autor que sigue probablemente la crónica eusebiana y, por otro lado, confirma que los archivos públicos de Roma custodiaron las copias de los textos de Filón, un dato ausente en la Historia eclesiástica de Eusebio. No obstante, más allá de la implicancia de estos argumentos, no podemos asegurar el grado de veracidad de la noticia de Miguel concerniente a la posible conservación romana del corpus filónico. Este dilema se acentúa cuando detectamos más información poco certera relacionada con otros hechos históricos, como es el caso de la embajada a Gayo y Filón.

Según el orden temporal de los acontecimientos históricos sucedidos durante el Imperio de Tiberio, Miguel afirma que Sejano ideó un plan para destruir a los judíos (6. 94, ed. CHAвот), narrado por Filón en un trata- do histórico perdido (Contra Flaco 1; Eusebio, Historia eclaesiástica 2. 5. 7). El plan en contra de los judíos habría sido continuado por Flaco durante su mandato. Las consecuencias derivadas de esta última persecución habrían motivado el envío de embajadores griegos y judíos a Roma para apaciguar el descontento de Gayo por los disturbios en su provincia egipcia. Hasta aquí Miguel no manifiesta errores cronográficos en su narración. Sin embargo, en los datos presentados a continuación combina noticias procedentes de distintas fuentes y elabora una historia particular:

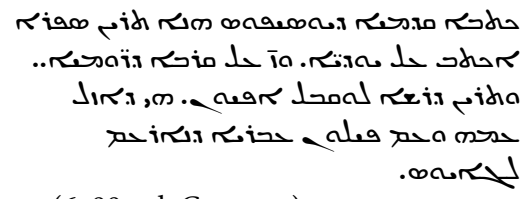

(6. 98 , ed. Снавот)

Primer libro de Josefo, quien escribió dos libros sobre los judíos, siete sobre la guerra de los romanos, y dos discursos contra Apión, quien fue con él y con Filón el hebreo ${ }^{51}$ para clamar ante Gayo.

Miguel declara que la embajada griega estaba formada por Apión, una noticia comunicada por Josefo en Antigüedades judías 18. 257-260, y reproducida por Eusebio en Historia eclesiástica 2. 5. 1. Sin embargo, en el momento de informar la compo-

51 Para el uso de "Filón el hebreo" en la tradición cristiana, cfr. Runia (1995: 39-43), quien afirma que la descripción de Filón como "el hebreo" comienza con Eusebio. Cfr. Historia eclesiástica 2. 4.2. 
sición de la delegación judía, coloca a Josefo nacido alrededor del año 38 como acompañante de Filón en la delegación dirigida a Gayo en el 38/39. Esta inexactitud histórica se repite en el Chronicon Syriacum de Bar Hebraeus, quien sigue el legado del patriarca en su ordenamiento de los sucesos cronológicos.

También conocido como Gregorio II Abu 'l-Faraj bar Ahron (ca. 12261286) o Bar 'Ebroyo, Bar Hebraues fue Mafrian ${ }^{52}$ desde el año 1264 hasta su muerte en 1286 (TAKAHASHI 2005: 22-27). Durante sus años de servicio, se educó en la historia secular y eclesiástica de los cronistas anteriores. En el Prefacio de su Chronicon Syriacum $^{53}$ demuestra que su historiografía depende posiblemente del Chronicon y la Historia Eclesiástica de Eusebio y, en gran medida, del Chronicon de Miguel el Sirio, como se desprende de su datación y ordenación temporal de los hechos en torno a la embajada ante Gayo. De la misma manera que Miguel, Bar Hebraeus introduce la audiencia de las delegaciones alejandrinas luego de comentar los atropellos recibidos por Jesús en el Imperio

52 Ubierna y Francisco (2018: 11, nota 6) definen "Mafrian" como "el obispo que estaba a cargo de los intereses de los miafisitas establecidos en las provincias orientales".

53 Bar Hebraeus anota los nombres de Sócrates el escolástico, Zacarías Rétor, Dionisio Telmarensi, entre otros. Jacobo de Edesa no es mencionado en este Prefacio. Su nombre surge en la datación del reino seleucida (libro VII), del Imperio romano (libro VIII), etc. Vuelve a aparecer en el Prefacio de la parte eclesiástica. Cfr. Abbeloos y Lamy (I 1872, ed. 3-5). de Tiberio, y las represalias sufridas por los judíos en el Imperio de Gayo, incluido el levantamiento de estatuas del César en el Templo, la historia del rey Abgar de Edesa y Jesús, con la muerte, resurrección y ascenso celestial de Cristo, además de la promesa de venganza contra los judíos por parte de Tiberio y el nombramiento de Agripa como rey de esta nación. Bar Hebraeus, entonces, parece apoyarse en orden temporal de Miguel, no $\sin$ alteraciones. Introduce la opresión contra los judíos en los siete años de la prefectura de Félix, que termina con la persecución del año 38 y el viaje de la delegación judía:

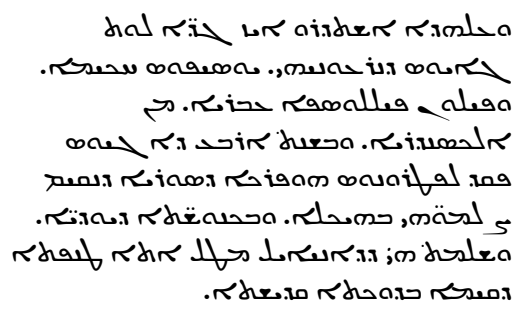

(...) a causa de esto, han sido enviados como embajadores ante Gayo para que cese: Josefo el sabio y Filón el filósofo hebreo de Alejandría. Y en el cuarto año de Gayo, ordenó a Patrono el gobernador de Siria colocar sus imágenes en el Templo y en las sinagogas de los judíos. Y así se cumplió lo que Daniel [dijo] acerca de un signo impuro en un lugar santo.

Este testimonio muestra que el Mafrian copia a Miguel en su construcción del evento de la embajada ante Gayo (Chronicon 6. 98, ed. СНАвот), o ambos utilizan una fuente común para reproducir esa noticia. Distin- 
tos de la tradición griega concentrada en repetir los datos ofrecidos por Filón en Contra Flaco y Embajada a Gayo, y por Josefo en Antigüedades judías, Miguel comete el error de formar la embajada judía con los nombres Josefo y Filón, que Bar Hebraeus reitera con otro cambio. En lugar de situar el evento de la persecución contra los judíos bajo la prefectura de Flaco, lo ubica en el gobierno de Félix, quien gobernó poco más de una década después sobre Judea (52-58 d.C.), y no sobre Egipto. Esta noticia extemporánea relativa a la región gobernada por Félix es parcialmente corregida por el mismo autor o un copista posterior en Historia Dynasticarum. Pese a la datación no cronológica del gobierno de Félix, la crónica árabe registra su nombramiento como juez de Jerusalén, no de Egipto, y su orden de introducir figuras idolátricas en los Templos judíos que habría motivado el viaje de la delegación encabezada por Josefo y Filón hacia Roma. El nombre de Flaco, por lo tanto, no está presente en la narración histórica de Bar Hebraeus. El autor atribuye a Félix la persecución contra los judíos y deriva la embajada a Gayo de su accionar.

Su Chronicon tampoco muestra un amplio conocimiento de la vida y obra de Filón. Fuera de los escasos datos acerca de la embajada a Gayo, el Mafrian establece una directa conexión entre Filón y los discípulos de Jesús. Sostiene que el alejandrino se encontró con el apóstol Pedro cuando predicaba en Roma bajo el gobier- no de Claudio (libro VIII), y escribió sobre aquellos recién convertidos a la fe cristiana, despojados de las posesiones e inquietudes mundanas, y concentrados en mantener una vida ascética en costumbres y pensamiento, educada en la sabiduría, y en el cuidado y uso necesarios del cuerpo. Es posible que esta descripción corresponda al tratado La vida contemplativa de Filón, pero este dato no es mencionado por Bar Hebraeus. Sus referencias sobre Filón concluyen con este encuentro probablemente ficticio, también anotado en Historia eclesiástica 2. 17. 1-24 de Eusebio y en la crónica de Miguel (6. 95, ed. Снавот). Junto con este brevísimo comentario sobre el encuentro entre Filón y Pedro, las noticias relativas a la embajada a Gayo son prueba de la repercusión del evento dado a conocer por Filón y repetido en las fuentes griegas, latinas y siríacas posteriores. La crónica de Bar Hebraues, entonces, es de interés sustancial para estudiar la transmisión de la historia de la embajada a Gayo y Filón, tanto en la historiografía siríaca como en la árabe. El Chronicon Syriacum y la Historia Dynasticarum, y el Chronicon de Miguel, abren un camino para continuar indagando este evento en los escritos de otros autores de la literatura siríaca y árabe.

\section{Estructura y contenido}

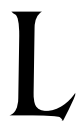

a distribución de los datos sobre Filón y la embajada a Gayo contenidos en los pasajes siríaco y árabe traducidos más abajo, está de- 
terminada por las referencias léxicas registradas en los textos. Pese a que la información revelada por estas partes no es amplia, el encadenamiento de los sucesos se puede dividir en las siguientes partes:

\section{Texto siríaco}

1) Introducción. Ubicación cronológica del Imperio romano.

2) Imperio de Tiberio César. Reina veintitrés años. Pilato es enviado como prefecto de Judea. Agitación judía por la introducción de la imagen del César en el templo. El rey Abgar de Edesa y Jesús. Muerte, resurrección y ascenso de Jesús. Abgar de Edesa y Tiberio contra los judíos. Tiberio promete vengarse de los judíos. Herodes y Herodías son exiliados y asesinados en la ciudad de Biana. Suma de la cantidad de años desde Adán hasta la muerte de Jesús.

3) Imperio de Gayo César. Reinó cuatro años. Gayo otorga a Agripa el gobierno de Filipo y de Lusania. Agripa mata a Santiago, hijo de Zebedeo. Félix, enviado como procurador a Egipto, persigue a los judíos durante siete años. Josefo y Filón son enviados como embajadores ante Gayo. El emperador ordena a Patrono, el gobernador de Siria, colocar sus imágenes en el Templo y en las sinagogas de los judíos. Agripa hizo un festival en Cesarea en honor al César. Fue herido y murió.
Texto árabe

1) Introducción. Ubicación cronológica de los emperadores romanos.

2) Tiberio César. Reina veintidós años. El gobernador Pilato erige una imagen del César en el Templo de los judíos. Cristo es bautizado por Juan. El rey Abgar de Edesa y Jesús. Ascensión de Cristo. Revelación de Dios al profeta Daniel sobre Cristo rey y su asesinato. Crucifixión de Cristo. Cantidad de años desde el comienzo del mundo hasta los seguidores de Cristo, según la Torá y la Septuaginta. Comparación de estas cantidades.

3) Gayo César. Reina cuatro años. Herodes Agripa es nombrado rey de los judíos por siete años. Félix es enviado a Jerusalén, y coloca ídolos en los lugares de culto de los judíos. Filón y Josefo viajan hacia Roma para solicitar audiencia ante Gayo. Petronio, enviado más tarde a Jerusalén, erige la imagen de Júpiter en el templo del Señor. Cumplimiento de la profecía de Daniel.

\section{Nuestra traducción}

O frecemos aquí la traducción del siríaco y árabe al castellano de las secciones Tiberio y Gayo del Chronicon Syriacum e Historia Dynasticarum de Bar Hebraeus. El texto siríaco utilizado para la traducción del Chronicon Syriacum es el Vatican City, Vatican Library, Syr. 166 
(Vat. Syr. 166, antes del año 1356/57), que ha sido cotejado con la edición de Bedjan (París, 1890) y la traducción inglesa de Budge (1932). El texto árabe pertenece a la edición de SĀLHĀNì (1890).

La división de los párrafos en la traducción sigue la estructura de los textos siríaco y árabe; con este criterio intentamos mantener la disposición del manuscrito Vat. Syr. 166 y del texto editado por SĀLHĀNī. Hemos agregado entre '[]' algunas palabras que, aunque ausentes en los textos en su lengua original, precisan el sentido de algunas expresiones confusas en el documento o confieren coherencia interna a una construcción oracional.
También añadimos algunas notas que buscan explicar variantes léxicas entre el manuscrito siríaco y la edición de BEDJAN, y distintas interpretaciones de vocablos, sintagmas o frases siríacas o árabes de difícil traducción.Sin embargo, hemos intentado elaborar una traducción que pueda leerse como texto autónomo, incluso con independencia de las notas al pie. Concientes de la problemática que implica la traducción de una obra de la cultura siríaca y árabe a una lengua moderna, hemos tratado de acercar lo máximo posible el original a los usos y expresiones de nuestra lengua castellana.

Chronicon Syriacum VIII: Tiberio y Gayo $^{54}$

Aquí ${ }^{1}$ comienza el octavo período: desde los reyes griegos paganos hasta los reyes de los romanos, cuando cesó el reinado de los ptolomeos, es decir, de los griegos en Egipto $^{2}$, y todo Egipto $^{3}$ y toda Siria quedaron bajo dominio de los romanos.

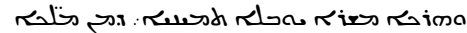

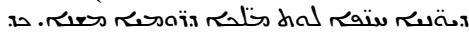

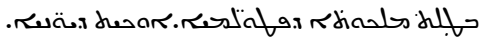
אפ נק נת حلi

Luego $^{4}$ de Augusto César [reinó] Tiberio César durante veintitrés años. Y en su decimocuarto año fue enviado el prefecto $^{5}$ Pilato para los judíos, siendo el procurador $^{6}$ sobre ellos. E introdujo la

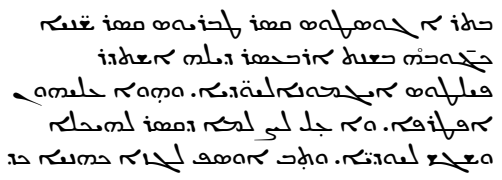

\section{Notas:}

1 Se trata del título del octavo período. Cfr. Vat. Sir. 166, f. 20 b 6-9.

2 "Egipto", Mר iּה, מצרים Misraim, Aegyptus. Cfr. Payne y Quatremére (1879).

3 "Egipto", a

4 A partir de aquí comienza la narración acerca de Tiberio. Cfr. Vat. Sir. 166, f.21a 17- f.21b 22.

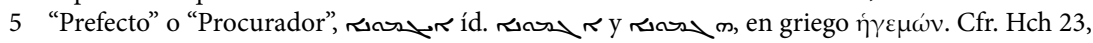
26; PAYNe y QuATremére (1879).

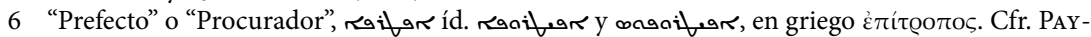
NE (1903).

54 La traducción al castellano y notas de este texto fue realizada a partir del siríaco original por Daniel AsADE, quien basó su trabajo en el manuscrito Vat. Sir. 166. o 
imagen del César en el templo, agitando a los judíos. Es más, procedieron con los tesoros de los sacerdotes cuando el acueducto llegó a la ciudad, causando un segundo disturbio. En el año decimonoveno de Tiberio, envió el rey $\mathrm{Abgar}^{7}$ de Edesa un cierto pintor llamado Juan ${ }^{8}$ el cartero a retratar a Nuestro Señor Jesús sobre un tablón, y se lo trajo a Abgar, quien envió una carta a Nuestro Señor a través de las propias manos de Ananías, diciendo: "He escuchado que [ciertos] poderes salen de ti, $y$ que tus curaciones son sin medicamentos, gratificante eres. Por lo tanto, o eres Dios que descendió del cielo, o el hijo de Dios. Debido a esto te he escrito y te rogué que te molestaras para venir a mí y cures la enfermedad que está en mí. También he escuchado que los judíos están envidiosos de ti, murmuran sobre ti y desean maltratarte. Una pequeña y hermosa ciudad tengo, suficiente para los dos". Nuestro Señor le respondió: "Bendito es quien ha creído en mí, aunque no me haya visto. Acerca de lo que has escrito de ir hacia ti ${ }^{9}$, es correcto que cumpla aquí las cosas para lo que he sido enviado, y luego seré elevado hacia quien me ha enviado. Inmediatamente un mensajero [remitiré] para ti, uno de mis discípulos que tu enfermedad sanará y salvación ${ }^{10}$ dará para ti y para quienes estén contigo. En el año decimonoveno de Tiberio sufrió Nuestro Salvador, murió, fue enterrado, resucitó y ascendió al cielo. Y en el día de Pentecostés una gran conmoción llenó a los sacerdotes de los judíos cuando escucharon una voz dentro del Templo que decía: "transitemos de este lugar". Abgar de Edesa le escribió a Tiberio
حل rioved dura and ram Rherid ",

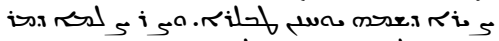
مdiv

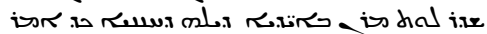

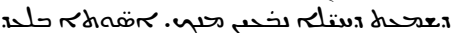

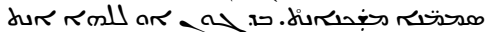

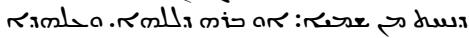

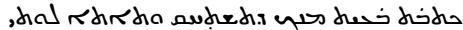

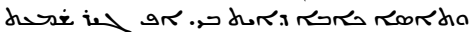
x.

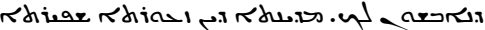

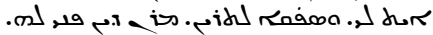
".

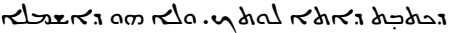

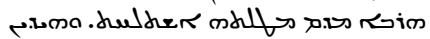

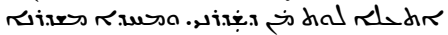

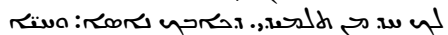

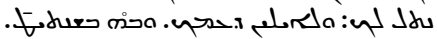
".

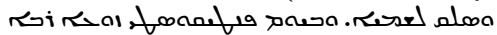

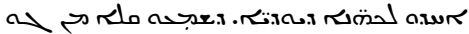

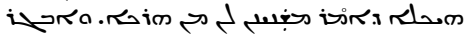
תוא.

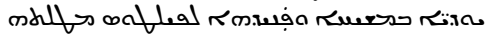
rir

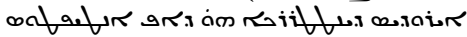

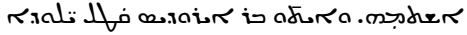

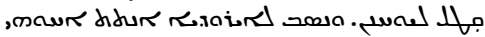

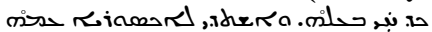

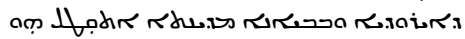

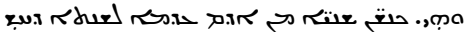

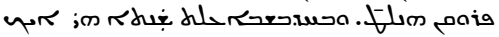

- קח

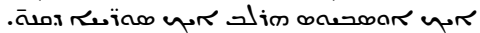

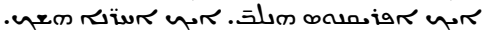

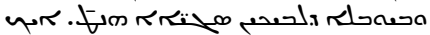

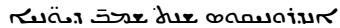

7 Cfr. Eusebio, Historia eclesiástica 1. 13; HowARD (1981).

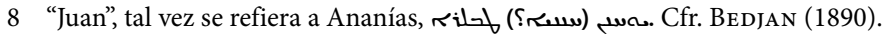

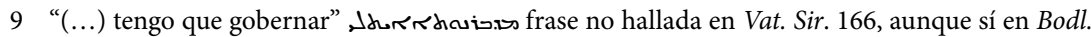
Hunt 52. Cfr.Principio del formulario Bedjan (1890); Budge (1932). A menudo utilizada para hacer referencia a los hechos realizados por Jesús en beneficio de la humanidad durante su vida terrenal. Cfr. PAYNe (1903).

10 El término siríaco es forma plural se refiere a un sustantivo abstracto que significa "vida", en el sentido de poseer el principio vital incluida la energía y la actividad. Cfr. PAYNE (1903); ORR (1939). 
acerca de todo lo que hicieron los judíos a Cristo. Y respondió: "He aquí a Pilato, que, a causa de esto, lo he dejado [caer] en desgracia, y de los judíos me vengaré". Herodes el tetrarca, también llamado Antipas, es el hijo de Herodes, el que asesinó a los niños y asesinó a Juan. Tomó [por esposa] a Herodías, la mujer de su hermano, estando vivo su esposo, $y$ ha sido enviado al exilio junto a Herodías. Y en la ciudad de Biana ${ }^{11}$ han sido asesinados él y ella. Sumamos la cantidad de años, desde Adán hasta el año del sufrimiento de Nuestro Señor: 5539. Y ese año comenzó el primer día de la semana ${ }^{12}$. Según Hipólito, Juan y Santiago: 5550. Según Eusebio: 5232. Según los siríacos: 4156. Según Africano: 5532. Según otros: 5320 . Y en otra tradición, según muchos: 5509. Según Andrónico fue en el año 342 de los griegos.

Luego $^{13}$ de Tiberio César [reinó] Gayo César durante cuatro años. Agripa, llamado Herodes, era hijo de Aristóbulo, hijo de Herodes el asesino de los niños por parte de María, hija de Hircano el Sumo Sacerdote. Cuando en tiempos de Tiberio subió a Roma para acusar al Tetrarca Herodes Antipas, fue encarcelado. Y mientras estaba encadenado suplicaba que sea Gayo el rey. Por eso cuando reinó [Gayo], le otorgó el principado de Filipo y de Lusania. A causa de esto maldijo Herodías a Herodes Antipas, porque [ella] no había ido al César: "has sido destituido del principado. Si Agripa que era simple, ¿cuánto más tú [podrías serlo] siendo de la Tetrarquía? Por eso cuando subió a Roma a recibir el reino, enojado Gayo lo condujo al exilio junto a su esposa, y allí murieron. En el primer año del reinado de Agripa mató

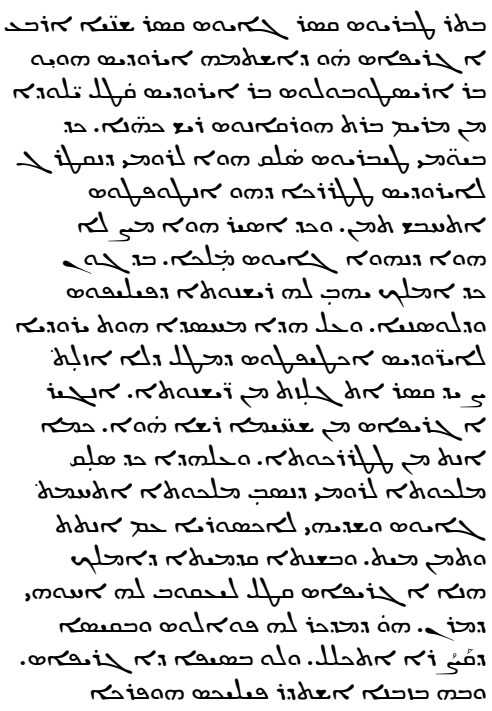

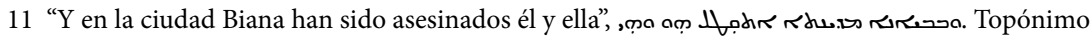
no hallado en los diccionarios convencionales. BEDJAN (1890) edita حسم que qudge (1932) traduce como "and both he and she were killed in the city of Bawinna (Winna?)". Bruns y Kirsch (1789) traducen Viennae.

12 “Domingo", wriva. Cfr. Payne (1903).

13 Aquí comienza la narración sobre el imperio de Gayo. Cfr. Vat. Sir. 166, f. 21b 23- f.22a 1-23. 
a Santiago, no al hermano de Nuestro Señor, sino al hijo de Zebedeo, a quien Pablo recuerda, y que por la madera del batanero ${ }^{14}$ ha sido coronado, ${ }^{15} \mathrm{y}$ no por la espada de Agripa. En aquel tiempo ha sido enviado Félix el gobernador ${ }^{16}$ de Egipto, quien ${ }^{17}$ presionó a los judíos durante siete años. $\mathrm{Y}$ a causa de esto, han sido enviados como embajadores ante Gayo para que cese: Josefo el sabio y Filón el filósofo ${ }^{18}$ hebreo de Alejandría. Y en el cuarto año del Santo ${ }^{19}$, ordenó a Patrono el gobernador de Siria colocar sus imágenes en el Templo y en las sinagogas de los judíos. Y así se cumplió lo que Daniel [dijo] acerca de un signo impuro en un lugar santo. Agripa entonces cumplió tres años de su reinado, y vino a Cesarea e hizo un festival de espectá$\operatorname{culos}^{20}$ por el bien de la vida del César ${ }^{21}$. $\mathrm{Y}$ en el segundo día de los espectáculos vistió la túnica tejida en plata, y vino a la mañana al teatro. Y cuando cayeron los primeros rayos del cielo sobre la plata, la hizo brillar admirablemente, y a causa de esto los aduladores lo llamaban "Dios". Como no los reprendía, fue herido por un obstáculo, y luego de cinco días llegó a su fin.

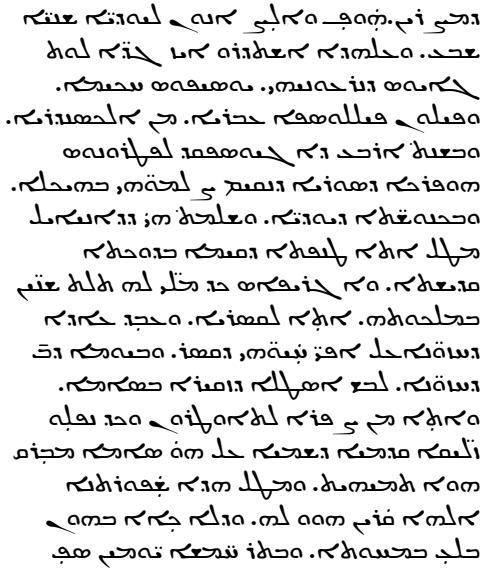

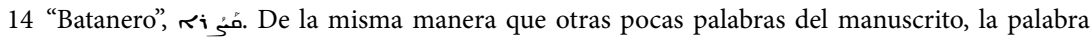
م مُ í se encuentra vocalizada según la tradición occidental. Cfr. 2 Re 18, 17; Is 7, 3; Is 36, 2; PAYNe (1903). "Batán" era una máquina generalmente hidráulica, compuesta de gruesos mazos de madera, movidos por un eje, para golear, desengrasar y enfurtir los paños. Consideramos que la traducción "corktree" ("árbol de alcornoque") propuesta por BUDGE (1932), es errónea.

15 "Ser coronado", لـ لـr, este verbo proviene de la raíz 2 , cuyo significado es "dar la corona del martirio". Cfr. PAYNe (1903).

16 "Prefecto", "procurador", "gobernador de una provincia", «iøam, en griego v้ $\pi \alpha \varrho \chi 0 \varsigma$. Cfr. PAYNE (1903).

17 "Este Félix", también "este gobernador", como se desprende de la abreviatura $\rightarrow$ ạ̣

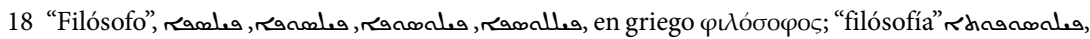

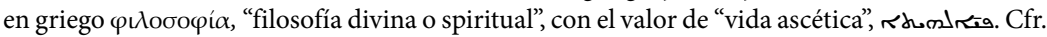
Payne (1903).

19 El copista de Vat. Sir. 166 escribe ond $ح$, que significa "santo". Bedjan edita øo几 nifica "Gayo". Cfr. Principio del formulario Bedjan (1890); Budge (1932). o

20 "Espectáculos", "juegos públicos", "concursos", «äw. Cfr. PAYne (1903). Budge (1932) traduce "and made a festival of theatricals".

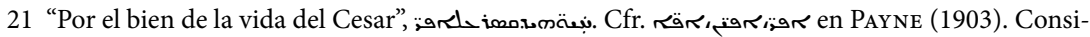
deramos que la traducción "representing the life of Caesar" de BuDgE (1932) es errónea. 
Historia Dynasticarum: Tiberio y Gayo ${ }^{55}$

\section{Séptimo período}

Transición desde los reyes griegos paganos hasta los reyes francos ${ }^{22}$

$$
\text { الدولة المنقلة من ملابعة الافرنج اليونانيين الوثنيين الى }
$$

(Tiberio César) $^{23}$. Reinó veintidós años. Durante el primer año de su reinado aconteció un gran terremoto, se destruyeron muchos sitios, y muchas personas y el ganado murieron. En su séptimo año construyó Herodes el hijo de Herodes la ciudad de Tiberíades en nombre del rey Tiberio. En el año decimocuarto el gobernador Pilato tomó medidas sobre los judíos, y erigió la imagen del César en el Templo perturbando a los judíos. Luego de tres años Cristo fue bautizado por Juan el hijo de Zacarías, un miércoles. Se dijo: el domingo, tres días después de enero $^{24}$. Él tenía treinta años. A partir de entonces comenzó a manifestar los signos $^{25}$ y revelar su experiencia acerca del reino de Dios exhortando a trabajar en el camino de la virtud y la justicia.Y en el decimonoveno año del rey Tiberio, es decir, en el año 342 desde la historia de Alejandro, envió Abgar el rey de Edesa mediante un tal Hanan una carta a Cristo, que dice: de Abgar el negro a Jesús el sanador ma-
(طيباريوس قيصر )ملك اثنتين و عشرين سنة.

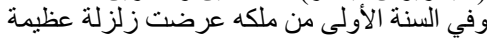
وسقط فيها مو اضع كثيرة ومات خلقي من من الناس

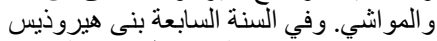

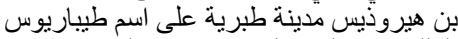

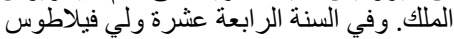

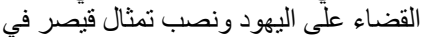

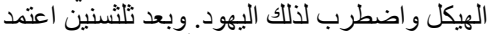

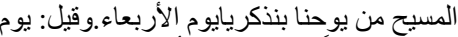

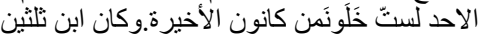

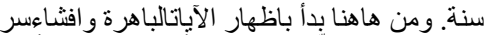

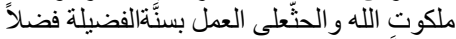

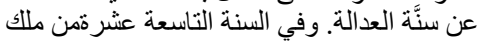

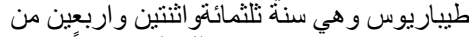

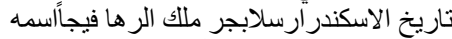

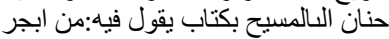

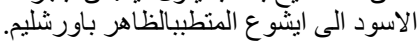

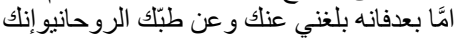

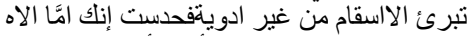

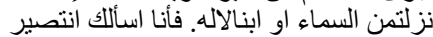

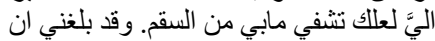

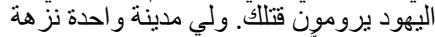

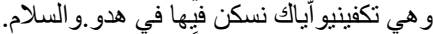

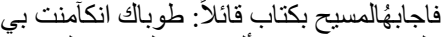

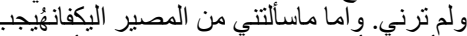

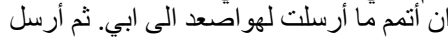

22 Denominación dada originalmente por los árabes a los franceses, y luego a todos los europeos. Cfr. Lane (1863).

23 Aquí comienza la narración sobre Tiberio César. Cfr. SĀLHĀNī (1890: 111-114).

24 “Se dijo: el domingo, tres días después de enero", وقيل: يوم الاحد لستّ خَلَونَ من كانون الأخيرة. Traducción dificultosa.

25 "Signos", الآيات, plural de آيّة. Un signo o marca por el cual se conoce a una persona o una cosa, posiblemente referido a un milagro. Cfr. LANE (1863).

55 La traducción y notas de este texto fue realizada a partir del árabe original por Daniel ASADE, quien basó su trabajo en la edición de SĀLHĀNì (1890). Agradecemos la ayuda brindada por el Dr. Elie WARDINI por sus consejos en la traducción de las palabras o frases árabes de significado oscuro o dificultoso. 
nifiesto en Jerusalén. Me he informado sobre ti y tu medicina espiritual, que absuelves los pecados, que no usas medicamentos, por lo que pensé que eres Dios descendido del cielo o el hijo de Dios. Te pregunto si puedes convertirme para así curar mi enfermedad. Me han dicho que los judíos quieren matarte. Tengo una ciudad de descanso, suficiente para que tú y yo vivamos en calma y en paz. Entonces Cristo le respon dió con una carta, diciendo: bendito seas porque creíste en mí sin haberme visto. Respecto de lo que me preguntas de ir hacia ti, debo cumplir para lo cual he sido enviado y ascender a mi padre. Luego te enviaré un discípulo mío para que sane tu enfermedad y te de vida eterna a ti y a los tuyos. Cuando Hanan tomó la respuesta de Cristo, lo miró y representó su imagen en un mandil ${ }^{26}$ porque era dibujante, lo llevó a Edesa y se lo dio a Abgar el negro. Se dice que Cristo se colocó este pañuelo limpiando su cara, imprimiendo en él su imagen. Luego de la ascensión de Cristo al cielo, condujo a un apóstol de los setenta y dos hacia Edesa y lo libró de su enfermedad. Ese año se cumplieron cuatrocientos noventa años desde que Dios le reveló al profeta Daniel que "setenta semanas tranquilizarán a tu nación y luego vendrá Cristo rey y será asesinado". Esto es si contamos desde los últimos veinte años del rey Artajerjes el de las manos largas, el año en el que Nehemías el copero fue enviado a Jerusalén, renovó el pacto mediante ofrendas, y Esdrás escribió el libro de la revelación.El decimonoveno año del rey Tiberio césar crucificó a Cristo un viernes veintitrés de Adar $^{27}$, cuando era la Pascua de los judíos el sábado. Pero Cristo no pudo lograr

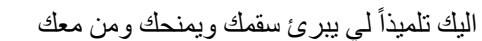

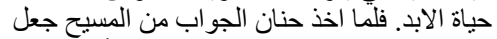

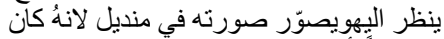

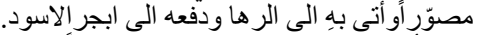

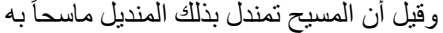

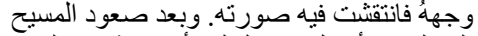
إلى السماء أرسل ادي السليح أحد الاثثين و السبعين إلى الرها وابر اهُ من سقاميه.

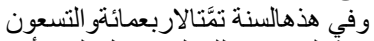

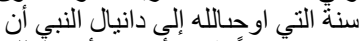

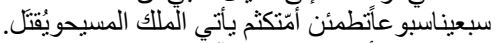

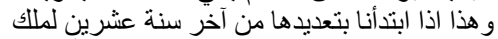

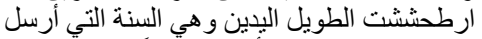

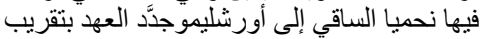
القر ابين وكتب عزر التب التب الوحي.وفي هذه السنة اعني التاسعة عشرة من ملك طيباريوس قيص فيصر

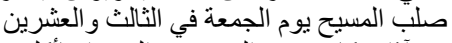

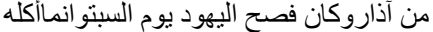

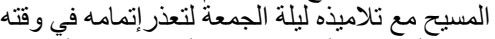

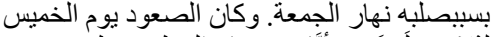

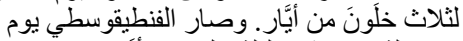

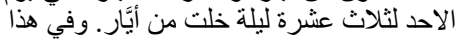

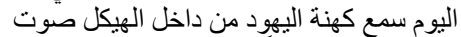

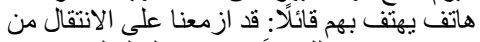

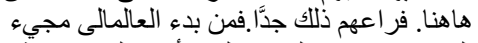

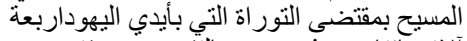

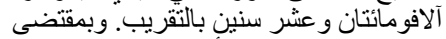

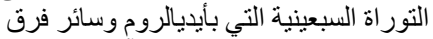

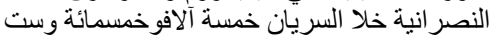
وثمانون سنة بالتقريب. ينقص التانئ خاريخ الأول من

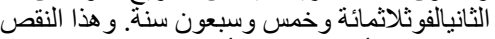

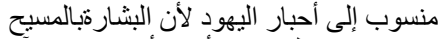

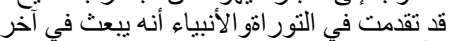

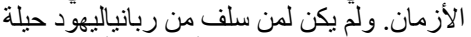

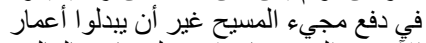

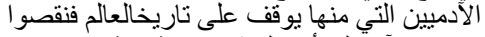
من عمر آدم إلى أن ولد شيث مائة سنة وز ادئ ادو ها في باقي عمره وكَذلك عملو أفي اعمار باقي ولا آدم ائ إبر اهيم.

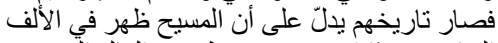

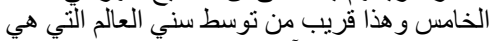

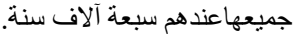

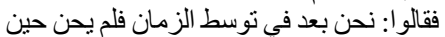

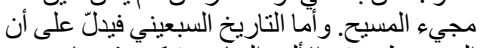
المسيح ظهر في الألف السادس فيكون قد حان حينه.

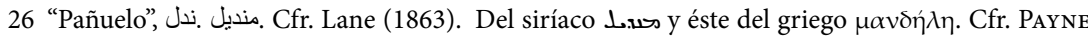
(1903).

27 “Adar", آذار, duodécimo mes del calendario hebreo, que corresponde aproximadamente a febrero y marzo. Cfr. Freedman (1992). 
comer a tiempo con sus discípulos la noche del viernes, debido a la crucifixión del viernes. La ascensión fue un jueves, tres días después de Ayar. ${ }^{28}$ Ese día escuchó el sacerdote de los judíos una voz desde dentro del templo que decía: "debemos transitar de aquí". Esto los asustó mucho ${ }^{29}$. Desde el comienzo del mundo hasta los seguidores de Cristo, según la Torá, que está en manos de los judíos, hay cuatro mil doscientos diez años. Según la Septuaginta, que está en manos de los bizantinos y todos los otros grupos cristianos salvo el siríaco ${ }^{30}$, cinco mil quinientos ochenta y seis años. La primera fecha respecto de la segunda tiene mil trescientos setenta y cinco años menos. Esta diferencia se atribuye a las crónicas de los judíos, ya que el anuncio de Cristo se ha adelantado en la Torá y los profetas, él resucita al final de los tiempos. No se adelantaron los rabinos judíos con una artimaña a inducir a los seguidores de Cristo, excepto para cambiar las edades de los humanos de quienes dependía la historia del mundo. Redujeron cien años la edad de Adán hasta que nació Set, y aumentaron el resto de su vida. También lo hicieron en el resto de las edades desde Adán hasta Abraham. La historia de ellos muestra que Cristo apareció en el quinto milenio, y esto está cerca de la intervención de la creación del mundo, que todos tienen siete mil años. Dijeron: "aún estamos a mitad del tiempo, y no es tiempo de los devotos de Cristo". Pero la historia de la Septuaginta muestra que Cristo apareció en el sexto milenio y que ha llegado el momento.

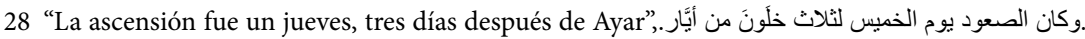
Traducción dificultosa. "Ayar" (árabe) e "Iyyar" (hebreo) corresponden al segundo mes del calendario hebreo, aproximadamente correspondiente a abril y mayo. Cfr. FreEdMan (1992).

29 "Esto los asustó mucho", فر اعهم ذلك جدًا, Traducción dificultosa.

30 Cfr. Freedman (1992) s.v. "Versions, Ancient (Syriac)". 
(Gayo César) $^{31}$. Reinó durante cuatro años. Durante el primer año de su reinado fue designado Herodes Agripa sobre los judíos por siete años. Y en este año mató Poncio Pilato a su clérigo y fue enviado Félix, un juez, a Jerusalén quien colocó ídolos en los lugares de culto de los judíos. Entonces enviaron al César dos sabios mensajeros, los hebreos Filón y Josefo, afectados por la acción. Entonces procedieron y suplicaron que retirara aquello que ofende a los judíos. En el cuarto año, Petronio, que llegó desde Roma a Jerusalén, erigió la imagen de Zeus, es decir de Júpiter en el templo del Señor. Y se cumplió la profecía del profeta Daniel, que dijo: habrá una señal impura donde no debería haberla.

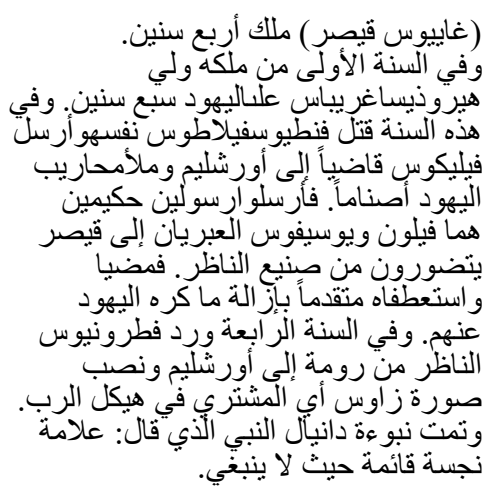

31 Aquí comienza la narración sobre Gayo César. Cfr. SĀLHĀNī (1890: 114-115).

\section{Manuscritos, ediciones y traducciones}

Abbeloos, J.B. y Lamy, Th.J. (1972). Gregorii Barhebraei Chronicon ecclesiasticum 1. Leuven.

AL-Mansūr, K. (1997). Ta'rikh mukhtasar ta'lif al-'́llāma Abì al-Faraj Ghrīghūriyūs b. Ahrūn al-malatī alma' rūf bi-Ibn al-'Ibrī al-mutawaffā sana 685 h. Wada'a hawāshīhi ... Beirut: Dar al-Kotob al-Ilmiyah.

Bedjan, P. (1890). Ktābā d-maktbānāt zabnē d-sim l-Mār Grīgōriyōs Bar 'Ebrāyā. Gregorii Barhebraei Chronicon syriacum. E codd. Mss. Emendatum ac punctis vocalibus adnotationibusque locupletatum. Paris: Maisonneuve, viii $+600 \mathrm{pp}$.

Bernstein, G. H. (1822). Gregorii BarHebraei Chronici syriaci e codd. mss. passim emendati atque illustrati specimett primum. Continens observationes et supplemena quaedam ad Ferd.
Gregorii Mayeri in hujus Chronici textum et versionem emendations. Leipzig: Vogel, 54 pp.

Bernstein, G.H. (1846). Die syrische Chronik des Bar-Hebraeus. Breslau: Grass, Barth \& Comp.

Bernstein, G.H. (1847). Ankuendigung und Probe einer neuen kritischen Ausgabe und neuen Uebersetzung der syrischen Chronik des Gregor Bar-Hebraeus. Berlin: Asher.

Brooks, E. W. (1899). “The Chronological Canon of James of Edessa", Zeitschrift der Deutschen Morgenländischen Gesellschaft, vol. 53.; 261-327.

Brooks, E. W., Guidi, I., y Chabot, J.-B. (eds.) (1905). Chronica Minora III. Leipzig: Otto Harrassowitz.

Bruns, P. J. y Kirsch, G. G. (1789). Ktābā d-maktbānāt zabnē l-mār Grīgōriyōs bar 'Ebrāyā. Bar-Hebraei Chronicon syriacum. E codicibus Bodleianis descriptum coniunctim ediderunt ... [in the translation volu- 
me: E codicibus Bodleianis descripsit, maximam partem vertit, notisque illustravit P. J. Bruns ... edidit et parte vertit, notasque adjecit $G$. G. Kirsch], 2 vols. Leipzig: Boehme.

Budge, E. A. W. (1932). The Chronography of Gregory Abü'l Fraj, the son of Aaron, the Hebrew physician, commonly known as Bar Hebraeus, neing the first part of his political [sic] history of the world. Translated from Syriac (vol. I), 2 vols. Oxford: Oxford University Press-London.

Снавот, J.-B. (1899-1924). Chronique de Michel le Syrien, patriarche jacobite d'Antioche (1166-1199), vols. I-IV. Paris: E. Leroux.

ÇIÇEK, Y. Y. (1987). Maktbānūt zabnē men rishā da-brìta 'dammā la-shnat $1285 \mathrm{~m}$. d-sìm l-yaddu'tānā rabbā Mār Grīgōriyōs Yōhannānmapryānā mshabbhā d-madnhā d-metdallal Bar 'Ebrāyā [The Chronography of Bar Hebraeus]. Glane/Losser: Bar Hebraeus Verlag.

FüCK, J. (1955). Die arabischen Studien in Europa bis in den Anfang des 20. Jahrhunderts. Leipzig: Harrassowitz.

Helm, R. ([ $\left.{ }^{1} 1913\right]$ 1956). Eusebius Werke 7: Die Chronik des Hieronymus, Griechischen Christlichen Schriftsteller 47.

Howard, G. (1981). The teaching of Addai. Ann Arbor, Mich: Society of Biblical Literature.

PocockiUs, E. (1663). Ta'rîkh mukhtasar al-duwal. Historia compendiosa Dynastiarum authore Gregorio Abul-Pharajio, Malatiensi Medico, Historiam complectens universalem, à mundo condito, usque ad Tempora Authoris, res Orientalium accuratissimè describens. Arabice edita, Latine versa $a b \ldots, 2$ vols. Oxford: [excudebat H. Hall, impensis Ric. Davis].
SĀLHĀNī, A. (1890). Ta'rīkh mukhtasar al-duwal li-l-'allāma Ghrīghūriyūs almalatī al-ma'rūf bi-Ibn al-'Ibrī. Beirut: al-Matbáa al-Kāthūlīk Piya lilābā’ al-Yasū'īyīn.

Schwartz, E. (1903-1909). Eusebius Werke: Die Kirchengeschichte (GCS IX/1-3). Die Lateinische Übersetzung des Eüfinus Bearbeitet im Gleichen Auftrage von Theodor Mommsen. Leipzig.

Vatican City, Vatican Library, Syr. 166 (pt. 1) = Vat. Syr. 166.

\section{Bibliografía crítica citada}

Aigle, D. (2005). "Bar Hebraeus et son public à travers ses chroniques en Syriaque et en Arabe". En Le Muséon 18 (1/2); 87-101.

Assemani, J. S. (1725). Bibliotheca Orientalis Clementino - Vaticana in qua manuscriptos codices Syriacos, tomo III: 1 . Roma.

Bagnall, R. S. y Frier, B.W. (1994). The Demography of Roman Egypt. Cambridge.

BArthélemy, D. (1967). "Est-ce Hoshaya Rabba qui censura le Commentaire Allégorique? A partir des retouches faites aux citations bibliques, étude sur la tradition textuelle du Commentaire Allégorique de Philon" en Philon d'Alexandrie. Lyon 11-15 Septembre 1966; Colloques Nationaux du Centre National de la Recherche Scientifique. Paris; 45-78.

BisCardi, A. (1983). "Polis, politeia, politeuma”. En Atti del XVII Congresso Internazionale di Papirologia, Napoli; 19-26.

Brock, S. P. (1976). "Syriac Sources for Seventh-Century History”. En Byzantine and Modern Greek Studies, vol. 2; 17-36. 
Brock, S. P. (1979). "Syriac Historical Writing: A Survey of the Main Sources". En Journal of the Iraq Academy, Syriac Corporation, vol. 5; 1-30.

Conrad, L. (1994). "On the Arabic Chronicle of Bar Hebraeus: His Aims and Audience". En Parole de l'Orient 19; 319-378.

Druille, P. (2015). "La situación cívica de los judíos en los tratados de Filón”. En Synthesis, 22; 125-138.

Druille, P. (2017). "P. Oxy. 1089 y la entrevista secreta de Flaco con los antisemitas Isidoro y Dionisio. Texto y traducción”. En Circe 21/2; 76-91.

Druille, P. (2019). "La gerousía judía en Alejandría romana del siglo I d.C.: $P$. Yale II, 107 y Contra Flaco de Filón". En Revue des études juives 178 (3-4); 325-361.

Fiey, J.-M. (1986). "Esquisse d'une bibliographie de Bar Hébraeus (+ 1286)". En Parole de l'Orient 13; 279-312.

Freedman, D. N. (1992). The Anchor Bible dictionary. New York: Doubleday.

Goodenough, E. R. (1926). "Philo and Public Life". En The Journal of Egyptian Archaeology 12, No. $1 / 2 ;$ 77-79.

Honigmann, E. (1934). "Zur Chronographie des Bar Hebraeus". En OLZ XXXVII; 273-283.

Keseling, P. (1926-1927). "Die chronik des Eusebius in der syrischen Überlieferung" [1-2]. En Oriens Christianus 23 (1926-1927), pp. 23-48, 223241 [=1]; 23 (1927), pp. 33-56 [=2].

Kurdian, H. (1938). "A Few Corrections in the English Translation and Transliteration of the Chronography of Gregory Abû'l Faraj (Bar Hebraeus)". En Journal of the Royal Asiatic Society of Great Britain and Ireland 3; 431.

Lane, E. W. (1863). Arabic-English Lexicon. London: Willams \& Norgate.
Martín, J. P. (ed.) (2009). "Introducción general" en Obras Completas de Filón de Alejandría, vol. I. Madrid: Trotta; 9-91.

Morris, J. (1987). “The Jewish Philosopher Philo" en SCHürer, E. (ed.). The History of the Jewish People in the Age of Jesus Christ (175 BC-AD 135), 3(2). Edinburgh: T\&T Clark; 809-889.

Mossay, J. (1981). "Eusèbe, Hist. Eccl., III, 30-38, dans le Ms. Princeton Mus. Art. Gr. Acc. 41.26”. En Le Muséon 94; 222.

Nallino, C. A. (1931). "Le fonti arabe manoscritte dellopera di Ludovico Maracci sul Corano". En Rendiconti della R. Accademia Nazionale del Lincei, Classe di scienze morali, storiche e filologiche, ser. 6, vol. VII; 303-349.

ORR, J. (1939). The International standard Bible encyclopedia. Grand Rapids: W.B. Eerdmans Pub. Co.

Payne, S. J., y Payne, S. R. (1903). A compendious Syriac dictionary: Founded upon the Thesaurus Syriacus of $R$. Payne Smith, D.D.

Payne, S. R., y Quatremere, É. M. (1879). Thesaurus syriacus. Oxonii: Typographeo Clarendoniano.

Roberts, C. (1963). Buried Books in Antiquity. London: Arundell Esdaile Memorial Lecture 1962.

Royse, J. R. (1980). “The Oxyrrhynchus papyrus of Philo". En The Bulletin of the American Society of Papyrologists 17; 155-165.

Royse, R. (1991). The Spurious Texts of Philo of Alexandria: A Study of Textual Transmission and Corruption with Indexes to the Major Collections of Greek Fragments. Leiden.

Runia, D. T. (1993). Philo in Early Christian Literature. A Survey. Assen-Minneapolis: Van Gorcum \& Fortress Press. 
Runia, D. (1995). Philo and the Church Fathers. A Collection of Papers. Vigiliae Christianae, Supplements, Vol. 32. Leiden: Brill.

SAmiR, S. K. (1980b). "Trois manuscrits de la chronique la chronique arabe de Barhebraeus a Istanbul". En OCP XL VI; 142-144.

Sandmel, S. (1981). "Philo Judaeus: An introduction to the Man, his writings and his significance". En Aufstieg und Niedergang der römischen Welt, II, 21/1.2 (1981); 3-46.

Sijpesteijn, P.J. (1964). “The Legationes ad Gaium”. En JJS 15; 87-96.

Smallwood, E. M. (1961). Philonis Alexandrini, Legatio ad Gaium. Leiden: Brill.

Smallwood, E. M. (1976). The Jews under Roman Rule. Leiden: Brill.

Takahashi, H. (2001). "Simeon of Qal'a Rumaita, Patriarch Philoxenus Nemrod and Bar 'Ebroyo". En Hugoye IV $/ 1$.

TAKahashi, H. (2005). Barhebraeus: a bio-bibliography. Piscataway, N.J.: Gorgias Press. Mazzola, M. (2018). "The Textual Tradition of Bar 'Ebroyo's Chronicle”. En Le Muséon 131 (1-2); 73-100.

Taubenschlag, R. (1955). The Law of Greco-Roman Egypt in the Light of the Papyri. 332 B.C.-640 A.D. Warszawa: Państwowe Wydawnictwo Naukowe.

Tcherikover, V. A. y Fuks, A. (ed.) (1957-1960). Corpus Papyrorum Judaicarum, vol. I-II. Cambridge, Massachusetts: Harvard University Press.

Terian, A. (1981). Philonis Alexandrini. De animalibus. SHJ 1, Scholars Press, Chico, California.

Teule, H. G. B. (1996). “The crusaders in Barhebraeus' Syriac and Arabic secu- lar chronicles: a different approach" en Ciggaar, K., Davis, A. y Teule, H. (ed.). East and West in the Crusader States. Context - Contacts - Confrontations. Acta if the congress held at Hemm Castle in May 1993 (OLA 75). Louvain: Peeters; 39-49.

Torallas Tovar, S. (2009). "Contra Flaco. Embajada a Gayo" en MARTín, J. P. (ed.). Obras Completas de Filón de Alejandría, vol. V. Madrid: Trotta; 177-301.

Ubierna, P. y Francisco, H. R. (2018). Apuntes de siríaco. Breve introducción a la lengua y literatura siríacas. Byzantina \& Orientalia. Adnotationes Linguarum I. Buenos Aires: Consejo Nacional de Investigaciones Científicas y Técnicas Instituto Multidisciplinario de Historia y Ciencias Humanas.

VAN Der Horst, P. W. (2003). Philo of Alexandria. Philo's Flaccus. The First Pogrom, Leiden.

Velasco-Delgado, A. (trad.) ([1973] 2008). Eusebio de Cesarea. Historia eclesiástica. Madrid: Biblioteca de Autores Cristianos.

Wiтакоwsкi, W. (1999-2000). "The Chronicle of Eusebius: Its Type and Continuation in Syriac Historiography”. En Aram 11-12; 419-437.

Witakowski, W. (2008). “The Chronicle of Jacob of Edessa" en HAAR ROMENY, B. ter (ed.). Jacob of Edessa and the Syriac culture of his day. Monographs of the Peshitta Institute, Leiden. Studies in the Syriac versions of the Bible and their Cultural Contexts, 18. Leiden-Boston: Brill; 25-47.

Recibido: 06-09-2019 